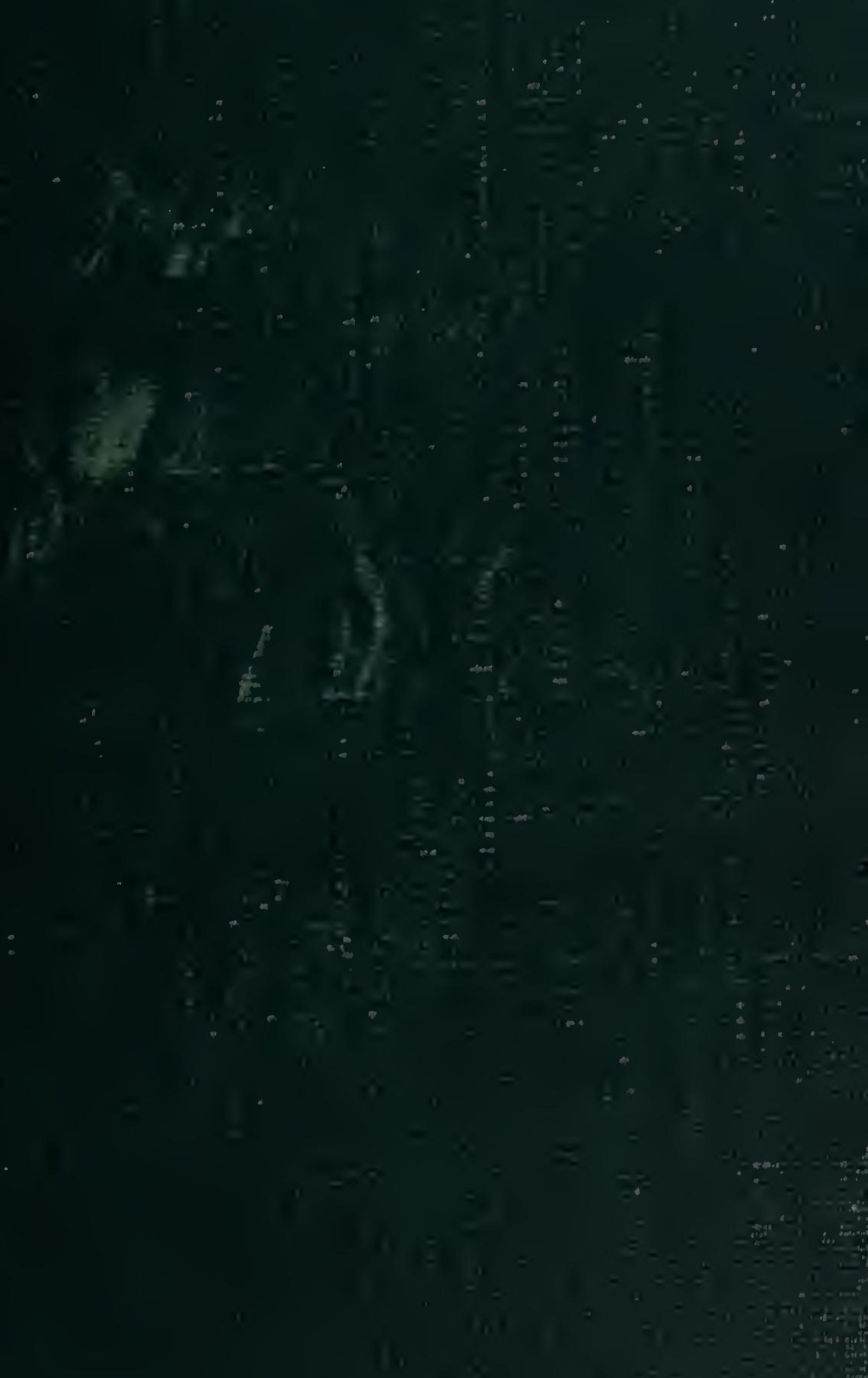

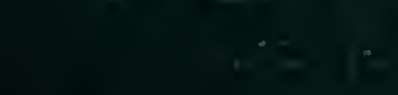

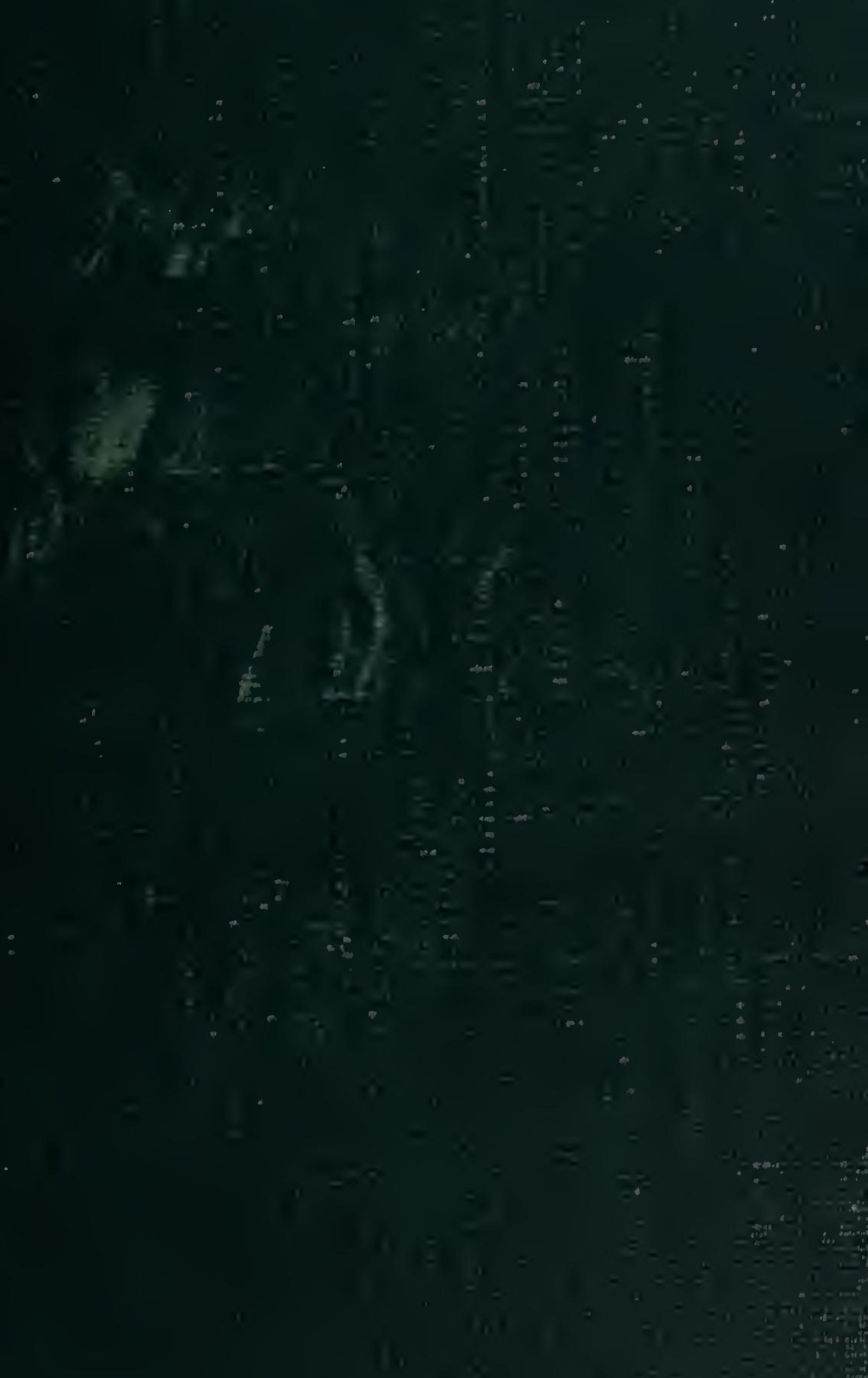
18 


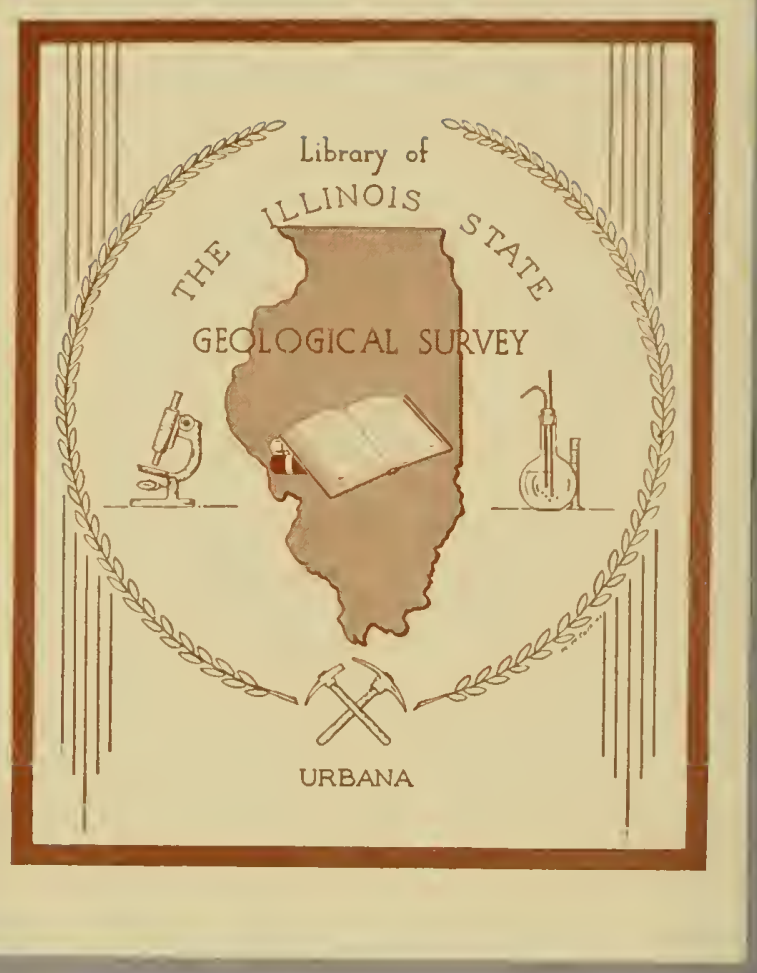


If

$\sqrt{3}$

(1)

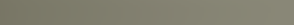

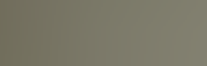

\section{and}



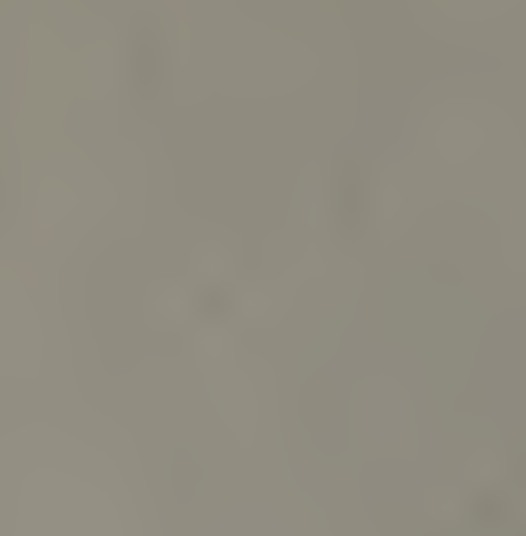

n.1.

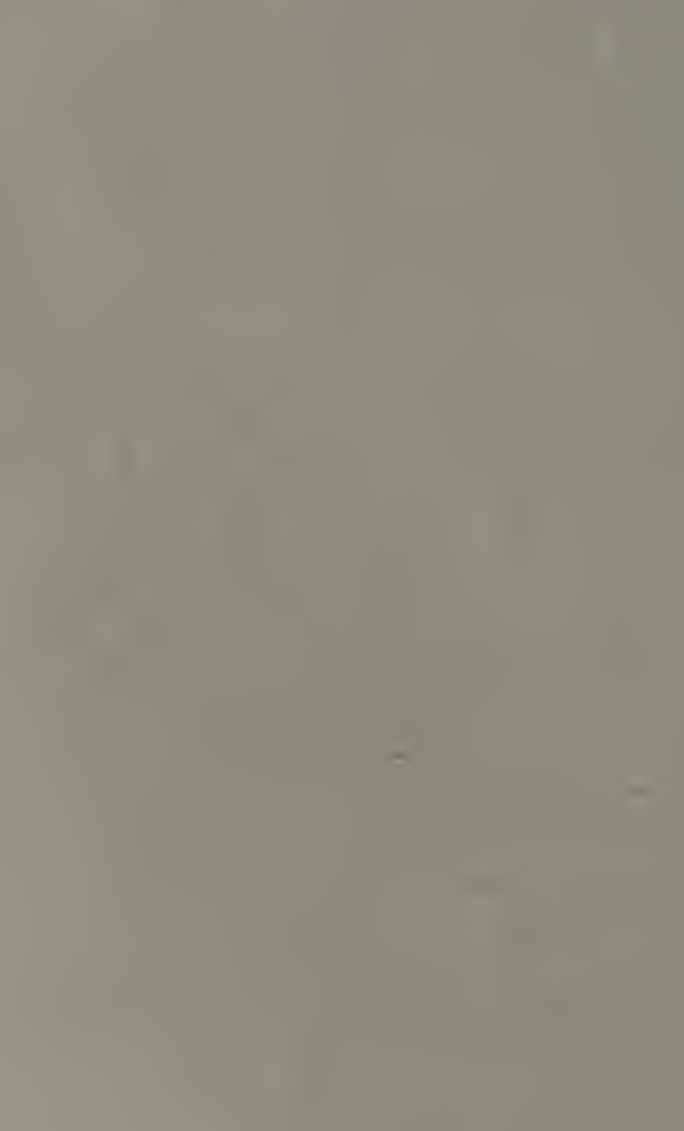


STATE OF ILLINOIS

DEPARTMENT OF REGISTRATION AND EDUCATION

DIVISION OF THE

STATE GEOLOGICAL SURVEY

M. M. LEIGHTON. Chief

REPORT OF INVESTIGATIONS - NO. 21

A GROUP OF LARVIFORM CRINOIDS FROM LOWER PENNSYLVANIAN STRATA OF THE EASTERN INTERIOR BASIN

BY

J. MARVIN WELLER

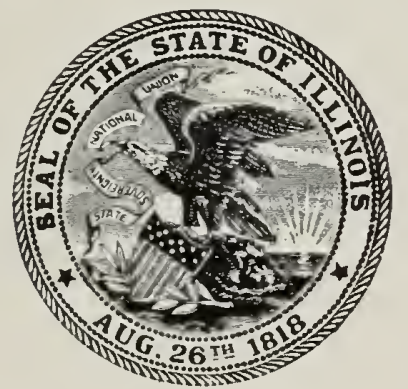

PRINTED BY AUTHORITY OF THE STATE OF ILLINOIS

URBANA, ILLINOIS 
STATE OF ILLINOIS

DEPARTMENT OF REGISTRATION AND EDUCATION

M. F. Walsh, Director

BOARD OF

NATURAL RESOURCES AND CONSERTATION

M. F. WaLsh, Chairman

Ensox S. Bastix, Gcology

William A. Noyes, Chemistry

JoIr.s W. Alrord, Engineering

William Treleise, Biology
Hexry C. Cowles, Bolany

Charles M. Thompson, Representing the President of the Unizersity of Illinois

STATE GEOLOGICAL SLRVEY DIVISION

M. M. Leightox. Chicf

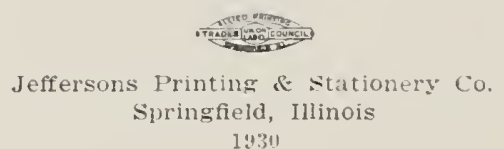

19311 


\section{Contents}

PAge

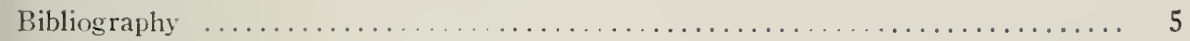

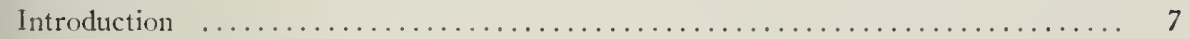

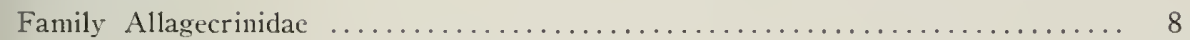

Genus Hybochilocrinus J. M. Weller, 11. gen................... 12

Hybochilocrinus americanus (Rowley) ....................... 13

Genus Kallimorphocrinus J. M. Weller, 11. gen.................... 15

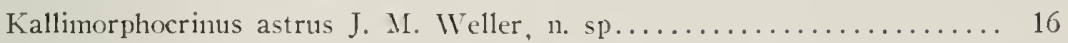

Kallimorphocrinus astrus typicus J. M. Weller, 1. var........... 17

Kallimorphocrinus astrus intermedius J. M. Weller, n. var......... 18

Kallimorphocrinus astrus pyramiclalis J. M. Weller, n. var........ 18

Kallimorphocrinus piasaensis J. M. Weller, 11. sp............... 18

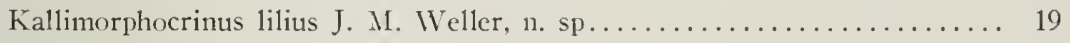

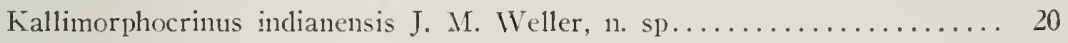

Kallimorphocrinus vanpelti J. M. Weller, 11. sp................ 21

Kallimorphocrinus infacetus J. M. Weller, 11. sp................ 22

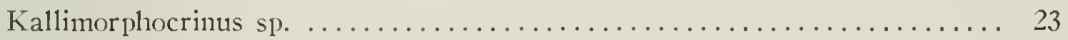

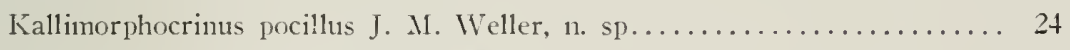

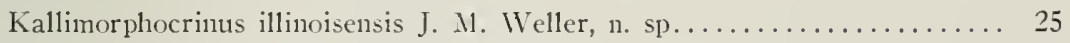

Kallimorphocrinus knighti J. M. Weller, n. sp................. 26

Kallinorphocrinus expansus J. M. Weller, 11. sp................ 27

Genus Aidemocrinus J. M. Weller, n. gen.................... 28

Aidemocrinus odiosus J. M. Weller, n. sp.................... 28

Family Hypocrinidae ...................................... 29

Genus Lageniocrinus, de Koninck and Le Hon..................... 31

Lageniocrinus cassidus J. M. Weller, 1 . sp.................. 32

Genus Amphipsalidocrinus J. M. Weller, n. gen................. 33

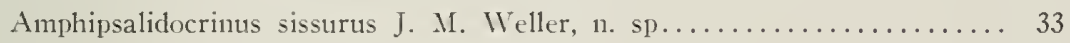

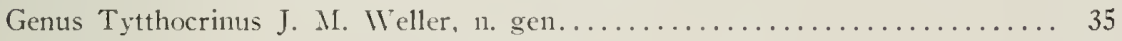

Tytthocrinus comptus J. M. Weller, n. sp.................. 35

Genus Dichostreblocrinus J. M. Weller, n. gen................. 36

Dichostreblocrinus scrobiculus J. M. Weller, n. sp.............. 37

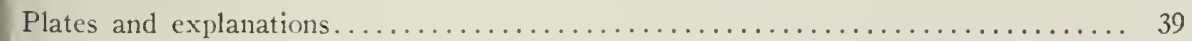


Digitized by the Internet Archive in 2012 with funding from University of Illinois Urbana-Champaign

http://archive.org/details/groupoflarviform55721 well 


\section{BIBLIOGRAPHY}

Text references to the bibliography are made by number, enclosed in brackets, thus$[17$, p. 10].

1. Bather. F. A., The Echinodermata; Lankester's Treatise on Zoology, Part 3, 1910.

2. Carpenter, P. H., and Etheridge, R., Jr., On Allagecrinus, the representative of a new family from the Carboniferous limestone series of Scotland; Annals and Magazine of Natural History, 5th series, vol. 7, pp. 281-298, Pls. 15-16, 1881.

3. De Koninck, L. and Le Hon, H., Recherches sur les crinoïdes du terrain Carbonifère; Recueil des Mémoires, l’Académie Royale de Belgique. 1854.

4. Jakovlev, N. N., Faune des Echinodermes du Permo-Carbonifère de l'Oural à Krasnooufimsk I; Bulletin du Committe Géologique de l' U. R. S. S. vol. 45, pp. 51-57, Pl. 1, 1926.

5. Jakovlev, N. N., Faune des Echinodermes du Permo-Carbonifère de l'Oural à Krasnooufimsk II : Bulletin du Committee Géologique de l' U. R. S. S. vol. 46, pp. 181-191, Pl. 6, 1927.

6. Jakovlev, N. N., Sur la tératologie et la morphogénie des crinoïdes abrachiates: Comptes Rendus de l'Académie des Science de l' U. R. S. S., pp. 313-315, 1928.

7. Rowley, R. R., Description of a new genus and five new species of fossils from the Devonian and Sub-Carboniferous rocks of Missouri; American Geologist, vol. 16, pp. 217-223, 1895.

8. Rowley, R. R., The geology of Pike County; Missouri Bureat of Geology and Nines, 2nd series, vol. 8, 1908.

9. Springer, F., Cystoidea, Blastoidea, Crinoidea; Eastman-Zittel TextBook of Geology, vol. 1, pp. 143-226, 1913.

10. Springer, F., On the fossil crinoid family Catillocrinidae; Smithsonian Miscellaneous Collections, vol. 76, No. 3, 1923.

11. Wachsmuth, C., Descriptions of two new species of Crinoidea from the Chester limestone and Coal Measures of Illinois; Illinois State Museum of Natural History, Bulletin 1, pp. 40-43, 1882.

12. Wachsmuth, C., and Barris. W. H., Paleontology of Illinois. Part 3; Geological Survey of Illinois, vol. 7, pp. 339-345, 1883.

13. Wachsmuth, C.. and Springer, F., Revision of the Palaeocrinoidea, Part 3, First Section; Proceedings of the Academy of Natural Sciences, Philadelphia, 1885. 
14. Wanner, J., Die permischen Echinolermen von Timor, 1 Teil ; Paläontologic von Timor, 6 Lieferung, 1916.

15. Wamner, J., Ueber armlose Krinoiden aus dem jungeren Palaenzoikum; Verhandelingen van het Geologisch-Mijnbouwkundis Genootschap) voor Nederland en Koloniën, Geologische Serie-Teil 5, pp. 21-35, 1920.

16. Wanner, J., Die permischen Krinoiken von Timor; Jaarbock van het Mijnwezen in nederlandsch Oost-Indië, Verhandelingen 1921, 3rd Gedeelte, 1923.

17. Wanner, J., Neue Beiträge zur kenntnis der permischen Echinodermen von Timor, I Allagecrinus, II Hypocrinites; Dienst van den Mijnlouw in Nederlandsch-Indië, Wetenshappilijke Mededeelingen, No. 11, 1929.

18. Zittel, K. A. von, Handlunch der Paleontologie, vol. 1, 1876-1880. 


\title{
A GROUP OF LARVIFORM CRINOIDS FROM LOWER PENNSYLVANIAN STRATA OF THE EASTERN INTERIOR BASIN ${ }^{1}$
}

\author{
By J. Marvin Weller
}

INTRODUCTION

Recent collections of Pennsylvanian fossils from Illinois, Indiana, and Missouri have produced a most interesting assemblage of mintute larviform crinoids which are unique in comparison with previously known American forms. The only descriptions of fossils with which they are at all comparable are of specimens collected from Lower Carboniferous strata in Scotland, and Permian beds in the Ural Mountains, and the island of Timor.

The American specimens which are the subject of this article were collected at three localities, namely. eastern Jersey County. Illinois, southern Warren County, Indiana, and in the vicinity of St. Louis, Missouri. In addition to these a single poorly preserved specimen was discovered in southNesterin Vermilion County, Illinois. All of the specimens except the last were discovered in the laboratory in the course of examining washed material for foraminifera, ostracoda. and other minute fossils.

These tiny crinoids, the largest of which is less than two millimeters in height, are associated with the abundant fragmentary remains of inoginate crinoids of familiar Pennsylvanian types. It would be natural at first to consider these specimens as representing immature stages in the growth of some of the associated larger and more conventional species, but only a brief examination reveals the fallacy of such a conclusion. The entire construction of the little crinoids is quite ristinct from anything previously known from these strata. The most abundant type, for which the generic name Kallimorphocrimus is proposed (p. 11), is monocyclic and without anal plates. If these represent the early stages of any common Pennsylvanian crinoids one or more anal plates, as well as infrahasal plates, should be present. Furthermore, the radials in this genus are highly specialized arm-bearers having articular facets suggestive of the Poteriocrinidae. In the majority of the species these plates have developed longitudinal median angulations which give the crinoid a pentagonal or star-shaped horizontal outline and furnish a wider surface above for the articular processes. It is scarcely conceivable that crinoids having such angulated raclials could represent the youthful stages of any known species of Pennsylvanian Poteriocrinidae. Also, the specimens of those species which are known from more than a single individual are with few exceptions quite uniform in size and similar in development. If these specimens are immature individuals a gradational series should be obtained

${ }^{1}$ It is with pleasure that I acknowledge the kindness of Mr. J. B. Knight, who has placed in my hands the specimens of three species which he collected in the vicinity of St. Louis, and my indebtedness to Professor J. Wanner of Bonn, Germany, for helpful suggestions and direction to the literature. 
rather than a number of distinct forms, some of which are represented by numerous individuals.

It is significant that the Indiana specimens occur at a lower horizon than the Illinois and Missouri forms, which are from stratigraphically equivalent heds, and are distinct specifically, indicating that these tiny crinoids were short-ranged forms. Although the individuals oltained are comparatively few in number, they were probalsly very abunclant, as in each case only a small amount of material was examined. The occurrence of these tiny crinoicls at widely separated localities and at several horizons, as well as their great diversity of form, suggest that they may prove valuable for stratigraphic correlation, and the micropaleontologist who is concerned with the Pennsylvanian formations may be required to inclucle the Echinodermata in his field of observation.

\section{FAMILY ALLAGECRINIDAE}

In 1881 Carpenter and Etheridge published a description, accompanied by two plates of excellent illustrations, of a group of very small and peculiar crinoids collected from the Lower Carboniferous limestone of Scotlanci, and proposed for them the name Allagecrimus austinii [2]. ${ }^{1}$ They were unable to assign these forms to any previonsly recognized family of the Crinoidea and therefore instituted a new family, the Allagecrinidae. This group, which was all included in the single species $A$. austinil, is diverse in character and contains forms which differ from each other in such important respects that they probably represent not only a number of different species lut also several generic types. Among the specimens studied by Carpenter and Etheridge are three fairly complete ones which they considered to he adult. These are figured on Plate XV which accompanies their article and the one represented lyy figures $2 \mathrm{a}, \mathrm{b}$, and $\mathrm{c}$, as it is the best preserved. should he considered as the type, and from it rather than from the group as a whole the characters of the genus may be known.

On Plate XVI of Carpenter and Etheridge's article are figured a numher of specimens which were considered to be immature individuals helonging to the same species as the "adult" forms. These smaller specimens all possess an oral pyramic which is apparently absent from the "adult" specimens. One individual of somewhat intermediate nature is shown in figures $7 \mathrm{a}$ and $\mathrm{b}$ on Plate XV-this resembles the "adult" forms in general but seenis to possess, sunken down between the radials, a small oral pyramicl. This specimen is the only connecting link hetween the "immature" and "adult" forms and had it not heen found it would not have occurred to Carpenter and Etheridge to join this whole group into a single species.

There are several important oljections to considering the smaller forms immature examples of the larger ones: (1) all of the "adlult" specimens

${ }^{1}$ Bracketed numbers rerer to bibliography, pp. 5-6. 
were obtained from a single locality whereas "immature" forms were collected at a number of other places, and it is highly improbable that if these were really immature specimens they should occur at most places without "adult" specimens associated with them ; (2) the "immature" forms are too diverse in character to all belong to the same species; (3) the plates which compose the calyxes of the "immature" specimens are joined together so solidly that they were not separated upon the death and decomposition of the animals that formed them, but in the larval forms of modern crinoids the plates are thin, porous, and not solidly joined together; (4) the specimens in our collection, which strongly resemble some of Carpenter and Etheridge's "immature" forms, are mature as is shown by the fact that numerous specimens of a single species are nearly all of uniform size and in the same stage of development-if they were immature it is highly improbable that all of the specimens should have died at the same stage in their development; (5) according to the interpretation of Carpenter and Etheridge the relative size of the oral vault must have decreased with the growth of the crinoid and at the same time the number of arms must have increased. Wanner's study of a large number of specimens from Timor has shown that neither of these suppositions is true but that the relative size of the oral dome and the number of arms are constant characters among the various sized specimens belonging to a single species $[17, \mathrm{p} .10]$.

It is concluded, therefore, that the "immature" specimens are not conspecific with the "adult" forms, and in this view Wanner agrees [17, pp. 10-11]. It remains to decide whether or not it is justifiable to retain them in the same genus.

Crinoids that have been described as Allagecrinus are few in number. From America there are A. carpentcri Wachsmuth [11, p. 40] which has recently been removed to the genus Catillocrinus by Springer, [10, p. 28] and A. ancricanus Rowley [7, p. 219] which is considered below in more detail. Foreign species are: A. multibrachiatus, and A. uralcusis Jakovlev [5, pp. 18t-185], and the variety of the latter nodocarinatus, which should probably be considered a distinct species, from the Ural Mountains; and A. indoaustralicus, A. jakozlcoi, A. intlatus, A. acutus, A. procerns, $A$. quinquelobus, A. excavatus, A. quinquebrachiatus and A. ornatus Wanner from Timor [17, pp. 15-27].

The foreign species described by Wanner and Jakovlev are apparently similar in most of their characters to those in our collections upon which the observations in the following discussion are based.

The crinoids under discussion resemible $A$. anstinii (as restricted to the "adult" specimens of Carpenter and Etheridge) in two respects: (1) the

2 Professor Wanner states that J. Wright has collected more than 300 "immature" specimens from bed No. 1 at Invertiel. Fife, and with them he found only one or two of
the "adult" forms. [17, p. 11, footnote.] 
dorsal cups are formed of a ring of low basals and five closely joined radials with no sign of an anal structure; (2) the upper surfaces of the radials bear well-developed articular processes and are extended horizontally into conspicuous muscle fields. But here similarities cease. The most conspicuous difference is the absence of an oral crown in $A$. austinii. Carpenter and Etheridge state that "there are no signs of its having been roofed over by a closed clone or vault of any kind. Had such a structure existed within the circle of radial plates, it would assuredly have been preserved in the original of figure 2, together with the ring of first brachials." [2, p. 28t.] If the oral crown had formed as important a part in $A$. austinii as in our species it would certainly have been preserved, as it is present in all of our specimens, none of which possesses even the lowest brachials. Even if A. austinii passed through a stage in its development when it possessed an oral crown similar to that of some of the "immature" specimens, the fact that this oral crown in the mature forms was no longer attached directly to the dorsal cup but was separated from it by perisome is a distinction of generic importance sufficient to separate it from species which at maturity retained the oral crown firmly atached to the radials. A second conspicuous clifference is the unsymmetrical development of the radials in $A$. austinii, whereas in our specimens pentamerous symmetry is nearly perfect. Even in A. jakoulcoi and A. inflatus Wanner the axillary radials are only slightly wider above than the radials bearing only one arm facet whereas below they are all of practically uniform width. A third point of difference is seen in the character of the articular surfaces of the radials. Judging from Carpenter and Etheridge's figures, A. austinii possesses a simple transverse ridge separating a concave leveling of the outer cdge of the radial, the dorsal ligamental fossa, from the generally concave surface of the muscle field. The large opening of the central canal occurs close to and often interrupts the transierse ridge. This differs from our species in certain respects as may be seen by comparing with the description of these structures presented on a subsequent page, as well as by a comparison of figure $1 d$ on Plate II with figures 1 b and $6 a$ of Carpenter and Etheridge on their Plate XV.

The question as to whether any of these recently discovered species should be referred to the genus Allagecrinus has been considered by Wanner [17, pp. 11-12] who concluded that there is not sufficient basis for separating them. However, Wanner took into consideration only two characters, numher of arms and relative breadth of articular facets, and he is probably correct in his judgment that neither of these characters is of sufficient importance to warrant a rivision. Nevertheless there are screral other characters to be considered. It is not known that Allagecrinus austinii (restricted) possessed an oral clome attached to the radials and until it is established that such a structure was present and was similar to the dome surmounting the more 
recently described species, doubt must remain. Aside from this point there are two significant differences between $A$. austinii (restricted) and the other crinoids. These are (1) the irregularly sized radials of the former, whereas the radials of the latter are nearly of similar width even in those species having axillary radials. The dissimilar radials in $A$. austinii would have caused the oral vault, if present, to be distorted and unsymmetrical. (2) $A$. austinii possesses five basal plates, but Wanner states that where the interbasal sutures are visible in the Timoran forms, the basal disc appears twofold, one suture lying in the right posterior radius and the other in the anterior radius [17, p. 5]. It is probable that if any of the Timoran species had possessed five basals Wanner would have observed the sutures in a few at least of his numerous well preserved specimens. No basal sutures have been seen in any of the American examples.

The Timoran and American forms differ notably from each other in twc respects. (1) In the Timoran species the opening of the axial canal is at the center of and interrupts the cross ridge of the articular facet and in this respect is similar to $A$. anstinii. In the American specimens, however, the opening of this canal is behind the cross ridge and in the bottom of the depressed muscle field, thus differing from the Scottish form. (2) The oral domes of the crinoids from Timor are in general star shaped and pyramidal, sloping more or less uniformly outward and downward to the radials. The individual oral plates are convex, the depressions along the interoral sutures forming radial furrows converging toward the center of the crown. In these furrows the arms lay when contracted. The Russian A. multibrachiatus is probably also of this type. On the other hand, the oral domes of the American species are rosettelike and flat topped, the outside of the orals descending abruptly to the radials below. Rather indistinct and steep radial furrows are present between the outer edges of the orals but these do not converge toward the center of the crown and between them the upper surfaces of the orals are distinctly concave. The Russian species A. malensis and its variety nodocarinatus are apparently also of this type.

An extended consideration of the facts presented above has resulted in the conclusion that our species and probably those described by Wanner and Jakovlev and the "immature" examples of Carpenter and Etheridge can not be referred to Allagecrimus as typified by figures 2a, b, and c of Carpenter and Etheridge's Plate XV. It is therefore necessary to erect a new genus, Kallimorphocrimus, for a certain group laving prominent oral crowns which up to this time have been included under Allagecrinus and of which our American species are typical. Whether or not the Timoran species should be included in this new genus is undecided at present.

As a result of the restriction of Allagccrimus austinii to the "adult" forms of Carpenter and Etheridge and the introduction of a new genus for 
our tiny American species, the question arises-can these forms be referred to the family Allagecrinidae? The American species in structure and appearance closely resenulle the pentamerously symmetrical examples described from Timor. 'These in turn cannot, accorling to Wanner's opinion, be separated generically from multi-brachiate forms. Finally the dorsal cup of $A$. jakorleri, the most abunclant many-armed East Indian species, closely resembles the less known $A$. austinii (restricted). It would appear therefore, to be most convenient, conservative, and probally correct to consider all of these crinoids as members of a single family and consequently the new genus Kallimorphocrimus is assigned to the family Allagecriniclae.

Wanner has been influenced by his observations on that peculiar series of crinoids which he included in the family Hypocrinidae, to conclude that the Timoran species referred to Allagccrinus are also the result of regressive evolution and were descended from more complicated forms [17, p. 13]. Also it is his opinion that the pentamorously symmetrical forms were derived, by a reduction in the number of arms, from those possessing axillary radials and as substantiating evidence he points out that in the highest Paleozoic beds of 'Timor the five-armed species greatly predominate.

This argument loses its significance in view of the numerous American lower Pennsylvanian species which are not accompanied by any forms possessing axillary radials. Moreover a proper undlerstanding of the so-called Allagecrimus amcricanus Rowley from the lowermost Mississippian reveals a primitive type of calyx from which the later forms may have been derived by progressive evolution. It appears therefore that Kallinorplocrinus, except for its specialized articular facets and the absence of an anal plate, is in other respects truly a primitive crinoid and was not derived by degeneration from a more highly specialized ancestral type.

In view of its possible bearing on the ancestry of Kallimorphocrinus, Allagccrimus amcricamus Rowley, which represents a more primitive but allied type, is here described. Because its peculiarities sharply differentiate it from all other known crinoids, the new, genus Iyboclitocrimus is introduced for its reception. This genus is also assigned to the Allagecriniclae.

\section{Genus HYBOCHILOCRINUS J. M. Meller, n. gen.}

Genotype Aldagecrinus americanis Rowley

Monocyclic larviform crinoids which are composed of three rings of plates as follows: (1) a basal disc the plates of which are rarely distinguishable-some specimens seem to inclicate that the basals are three in number one being somewhat larger than the others, but the orientation of this larger plate is uncertain; (2) five nearly equally sized rarlials: (3) five orals, the

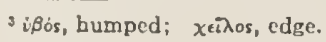


posterior one heing somewhat larger than the others, its inner angle extending between the anterior orals for a short distance thus completely separating the two postero-lateral orals from each other. In addition to these three rings of plates a single small anal plate rests upon the beveled upper lefthand corner of the right posterior radial and extends upward above the upper surfaces of the radials. The radials were all arm-bearing and in most specimens only a single arm was present upon any one radial. A few rather poorly preserved individuals may possess radials which are axillary but this can not be stated as a certainty.

The single species for which this genus is erected is similar in a general way to the forms of Kallinorphocrimus described on subsequent pages. It is however a more primitive type as shown by the presence of an anal plate which has been completely lost in the Pennsylvanian genus, and by the less highly specialized arm facets. It is possible that these forms represent a stage in the evolutionary history of Kallimorphocrinus.

\section{HyBochiLOCRints AMERICANus (Rowley)}

Plate I, figs. la-c

1895 Allagecrinus americanus Rowley, Am. Geol. vol. 16, p. 219, figs. 3-10.

Louisiana limestone; Louisiana, Missouri.

1908 Allagecrinus americanus Rowley, Missouri Bur. Geol. ser. 2, vol. 8, p. 67, pl. 16, figs. $39-41$.

Louisiana limestone; Louisiana, Missouri.

The only previously known American crinoid which bears even remote resemblance to the Coal Measures species of Kallimorplocrinus is Allagccrimus americanus Rowley from the Kinderhook beds of Pike County,

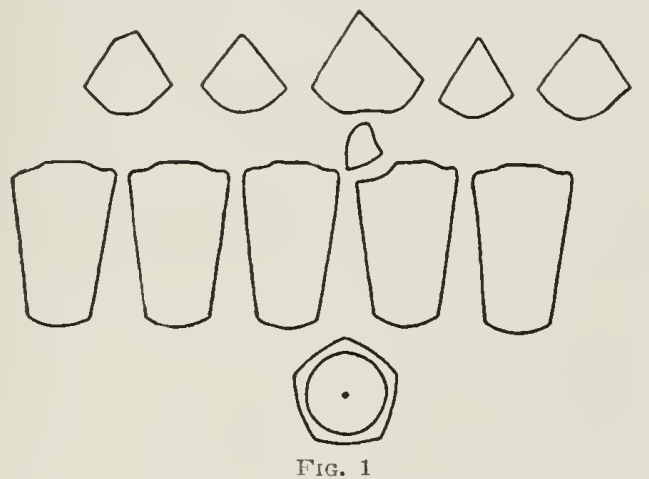

Plan of the calyx of Hybochilocrinus amcricanus

Missouri. For the sake of comparison with the Coal Measures species a description of this interesting Lower Carboniferous form is here inclucled. The material available for study consists of about one hundred specimens collected from the type locality in 1896 by Professor Stuart Weller. 
Description.-The calyx is very small, averaging about $1.3 \mathrm{~mm}$. in height. The height is considerably greater than the maximum width, giving the body a general pyriform shape which varies in some specimens to truncaterl conical or truncated sub-pyramiclal. The radials constitute more than half the total height and the basals make up somewhat more than half of the remainder.

The basal ring is circular in outline and enlarges slightly and more or less regularly upward above the stem facet which occupies the entire proximal surface. The surface of this portion of the calyx shows no indications of sutures lut one individual whose base was broken appears to have three basal plates one of which is somewhat larger than the others. The basals of this specimen apparently dicl not form a hasal cup. lut extended solidly to the center.

The radials are elongated and wider above than below. Their height is equal to twice their mean width or more. A broken specimen shows that the plates are about $.08 \mathrm{~mm}$. thick. The radials are gently convex longiturlinally and more strongly so transversely. The transverse convexity is either regular, resulting in a circular cross-section of the calyx, or it is somewhat accentuated along the central part of the radials, producing a calyx with slightly flattened sides along the middle of which extend the interadial sutures. The distal surfaces of the radials bear the brachial openings and the corners of the radials upon either sicle are more or less steeply notched producing concave depressions into which the orals extend.

Rowley reported that in some of his larger specimens the radials are axillary but this condition was not observed in any of our individuals examined. The specimens are all highly calcified and many of them apparently mote or less worn so that it is difficult to determine their detailed structure. The lest specimens examined, and these are all comparatively large examples. did not possess more than one arm to a radial.

This species has no well developed articular facets similar to those of Kallimorphocrinus. The position of the arms is inclicated ly a small suboval or rectangular (lepression on the upper surface of each raclial surrounded by a thin lip which extends directly upward from the ratial with whose surfaces it is continuous. There is no beveling of the radial below this lip, the outer portion of which is probably morphologically similar to the transverse ridge in Kallimorfhocrinus. The brachial openings surrounded by the lips are directed straight upward and are very narrow and lepressed owing to the size of the oral crown which covers a large part of the ventral surface. The general appearance of the brachial openings suggests that the arms of this crinoid possessed no well organized supporting calcareous slieleton.

A subhemispherical oral crown sumounts the calyx and occupies the greater part of its ventral surface. It is composed of five plates of which the posterior one is the largest. being both wider and longer than the others. 
The outer border of this plate is not as uniformly convex as the others but possesses a shallow concave indentation near the center in which the anal plate fits. The upper surfaces of the four small oral plates bear shallow indistinct concave depressions and the larger posterior plate has two somewhat narrower but otherwise similar depressions.

A peculiar structure at the upper left-hand corner of the right posterior radial is commonly well shown by the larger specimens, although in a few smaller individuals this is definitely not developed and pentamerous symmetry rules. The majority of the crinoids however are so poorly preserved that its presence or absence can not be determined with certainty. The upper right-hand portion of this radial bears a brachial opening of the usual type but the left-hand corner is distinctly beveled and meets the next radial at a position some distance below its upper surface. The inner surface of this beveled corner slopes steeply inward and downward from its sharply angular outer edge, apparently forming an opening that leads into the interior of the calyx beneath the oral crown. A very few specimens, instead of a beveled corner of this radial, show in this position a rounded projection extending above the upper surface of the radial nearly to the height of the top of the oral crown. Although no suture is visible there is little doubt that this projection is a separate plate which has been lost from most specimens. Rowley did not notice such a projection of one of the radials but he suggested that the beveling of the corner of the radial might represent the anal area. This extension of the upper left-hand corner of the right posterior radial probably represents a radianal plate which has been pushed upward and nearly out of the calyx. The specimens show no indication of an anal opening and it is probable that the rectum was situated within the oral plates which were capable of being opened during the life of the crinoid.

The surface of the plates of these crinoids is unornamented and was probably smooth. The specimens show minutely pitted surfaces but this may be due to wear or to slight solution.

Remarks.-This species is structurally distinct from all other known crinoids.

Occurrence.-This tiny crinoid is known only from a shale parting in the Louisiana limestone at Louisiana, Pike County, Missouri.

Genus KALLIMORPHOCRINUS ${ }^{4}$ J. M. Weller, n. gen. .

Genotype Kallimorphocrinus astrus typicus J. M. Weller, n. sp., n. var.

Monocyclic larviform crinoids of fairly perfect pentamerous symmetry, composed of three rings of plates: (1) a low disc of anchylosed basals; (2) five, high, nearly uniformly sized radials; and (3) five petaliform orals.

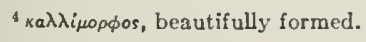


The upper sides of the radials, which are perhaps axillary in a few species, usually hear well-developed articular processes and extend horizontally inward as prominent muscle fields. The articulation consists of a strong transverse ridge below which the radial is more or less sharply beveled, and in a few specimens a small ligamental pit is visible near the center of the outer side of the ridge. Fxtending inward from the ends of the transverse ridge and separated from it by shallew grooves are two strong raclial ridges inclosing a concave area or muscle field near the middle of which is the small opening of the axial canal. 'The ventral surface is covered by the oral crown which rises strongly above the radials. The oral plates alternate with the radials and their upper flattened suriaces are broadly and shallowly concave. The ambulacral openings are between the orals at a position shightly above the the upper surface of the radials. The oral plates are nearly uniform in size but the posterior plate nay be distinguished by the fact that it adjoins both the right and left anterior orals near the center of the crown, thus separating the right and left posterior orals from each other. The posterior oral is a madreporite and its minute perforation may be seen on well preserved individuals. On some specimens a tiny pustule marks the position of this pore. The arms and the stem beyond its uppermost joint, which in many specimens remains attached to the calyx, are unknown.

The species Kallimorphocrimus astrus as represented by its typical variety is selected as the genotype, several well preserved specimens of which are inclucled in our collections. This variety is an extreme representative of the genus characterized by its pronounced star shape which has resulted from the development of the angulation of the radials producing wide and comparatively short articular facets. The other extreme is represented by $K$. pocillus with its lobate horizontal outline. The articular facets of this latter species are much longer than in the genotype and the description of their characters has largely been made from an examination of this species.

The specimens of Coal Measures Kallimorphocrimus exhibit considerable diversity of form and ornamentation on the basis of which they are divided into ten species.

\section{Kalliarorphocrinits Astrus J. M. Weller, 11. sp.}

In the collection from the Indiana locality the majority of the small crinoids that belong to this genus form a rather variable series and it has not been found practicable to subdivide them specifically. One of the conspicuous end members has been selected as typical and two members of the principal series are described as subordinate varieties. As may be seen from figures 2a, 3a, and 4a on Plate I, the prominence of the spinelike processes of the radials varies regularly as the diameter of the basal stem facet and inversely as the height of the basal clisc. In acklition to the three described 
varieties the collection contains several other forms most of which are smaller than the figured varieties so that it is not certain that they are mature individuals and for that reason they are not considered here.

\section{Kallimorphocrinus astrus typicus J. M. Weller, n. var.}

Plate I, figs. $2 a-c$

Description.-The height of the holotype is $1.07 \mathrm{~mm}$. and its maximum width is somewhat greater. Its horizontal outline is decidedly star shaped with rounded corners separated by broadly concave sides. The radials form about three-fourths, the underlying basal disc one-twelfth, and the crowning orals about one-sixth of the total height. Some specimens possess a thin stem joint firmly attached to the basal plates.

The basals are firmly anchylosed into a low basal disc which slopes regularly upward and outward to the suture which separates it from the radials. It is pentagonal in outline and its upper and outer edge is beveled for the reception of the radials. The circular stem facet occupies the whole

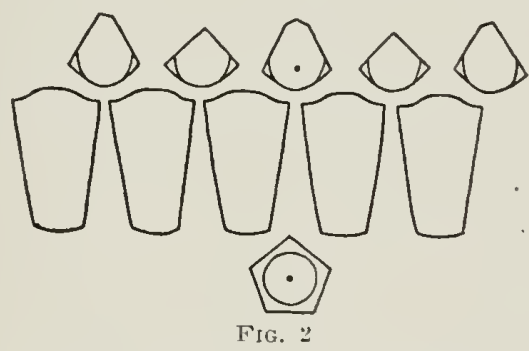

Plan of the calyx of fillimorphocrinus astrus

lower surface of the basal disc, is slightly concave, and is pierced by a single small central opening.

The radials are of sinilar size and form, subrectangular in outline but somewhat wider above than below. Their height is about twice their mean width. At their bases the radials are evenly convex but almost immediately a rounded central keel is developed which becomes more prominent upward owing to a widening of its flat lateral slopes. This angulation culminates above in a prominent rounded knob the top of which bears the articular facet for the arm. The upper corners of the radials are rather strongly beveled and rounded, producing between the radials broad concave depressions in which the orals rest.

The articular facets of the radials are much smaller than in $K$. pocillus. In few specimens are the details of this structure recognizably preserved but some specimens show a concave depression in the center of which lies the 
small opening of the axial canal, and on the whole they seem to be entirely comparable to those of $K$. pocillus.

The orals are relatively large and form a five-lobed flat-topped crown which rises abruptly above the radials. The outer portions of the sutures which divide them lie in broarl concave depressions and the outer portions of the orals slightly overhang their junction with the radials below.

The best preserved individuals of the $K$, astrus series are minutely pitted and as they are very perfectly silicified there can be little cloubt that this represents the original spicular structure of the plates which were somewhat porous.

Occurrence.-These specimens were collected from a limestone near the base of the Pennsylvanian section near the center of the $\mathrm{N}$. $\mathrm{T} / 2$ sec. 35 , T. 21 N.. R. 9 W., Warren County, Incliana.

\section{Kallimorphockinus Astrus intermedius J. M. Meller, n. var.}

Plate I, figs. $3 \mathrm{a}-\mathrm{c}$

This variety differs from the typical one in having its greatest width approximately equal to its height. The basal stem facet is smaller, the basal disc higher and the knob-like processes of the radials are much less developed so that the horizontal outline is nearly pentagonal.

Occurrence.-Same as the typical variety.

\section{KALLIMORPHOCRINUS ASTRU'S PYRAMIDALIS J. M. IVeller, n. var.}

Plate I, figs. $4 a-c$

This form is furthest removed from the typical variety of the $K$. astrus series. Each of the changes noted in the variety intermedius has progressed still further. In this form the height is greater than the width, the basal disc is higher, the stem facet smaller and the knobs on the upper part of the radials only slightly developed.

Occurrence.- Same as the typical variety.

\section{Kaldiarorphocrines piasaexsis J. M. Weller, n. sp. Plate I, figs. 5a-b}

Description.-The height of the holotype is $1.02 \mathrm{~mm}$. and is equaled by the greatest width. The horizontal outline is star-shaped with slightly rounded angles and concave sides. The radials form a little over two-thirds, the basal disc one-ninth and the oral crown one-sixth of the total height of the calyx.

The basal disc is subpentagonal as viewed from below and has a diameter equal to shightly more than one-fourth of the greatest width of the calyx. The plain sides of the disc slope outward and upward from the stem facet 
which occupies its whole lower surface. The radials rest in scallops which indent the upper and outer edge of the disc.

The radials have a height equal to twice their mean width and are about twice as wide above as below. They are extended into a median longitudinal angulation which rises abruptly from the general curvature of the calyx at the base of the radials and becomes increasingly prominent upward. The lateral slopes from the angulations of adjoining radials meet at the suture to form the sides of the calyx which becomes increasingly concave upward. The angulations of the radials terminate above in slightly expanded knoblike processes or are terminated by the beveling which leads upward to the arm facets. The upper corners of the radials are rounded off and at their junctures are concave depressions into which the orals extend.

The articular facets of the radials are not well preserved in the single known specinen of this species.

The oral crown rises strongly ahove the radials and slightly overhangs the dorsal cup interradially. The upper surface of each plate bears a broad shallow depression and a small pustule marks the position of the madrepore in the posterior radial.

The surface of the calyx is marked by closely set, very minute pits which probably indicate that the plates were originally porous.

Rcmarks.--This species is distinguisher from $K$. astrus by its stellate outline which is unaccompanied by prominent radial knols, and by its more coarsely pitted surface.

Occurence. - The holotype was obtained from shale immediately underlying the Piasa limestone ${ }^{5}$ near the center of the NE. I/4 sec. 25, T. $8 \mathrm{~N}$., R. $10 \mathrm{IV}$., Jersey County, Illinois.

\section{Kallimorpiocrinus LiLit's J. M. Weller, n sp.}

\section{Plate I, figs. 8a-b}

Description.-The height of the holotype, not including the stem joint attached to its base, is $.81 \mathrm{~mm}$., which is slightly less than the greatest width. A horizontal cross-section through the upper part of the radials is like a five-rayed star with somewhat rounded puints. The radials form about fiveeighths, the basal disc one-eighth, and the oral crown a little more than onefourth of the total height.

The basal disc slopes outward and tpward and supports the radials on its upper beveled edges. Its flat circular basal facet is completely covered by a stem joint.

The radials are considerably wider above than below and their mean width is somewhat greater than half their height. A longitudinal keel occu-

5 The Piasa limestone occurs about 20 feet above the limestone cap-rock of the Herrin No. 6 coal. It is correlated with one of the limestones of the Ilenrietta formation of
Missouri and Kansas. 
pies the center of each radial, becoming sharper and more prominent above and terminating in a small, narrowly rounded or sulsungular knol). The upper corners of the radials are beveled, forming rounded depressions in which the orals rest.

Articular processes are not preserved on any of the radials. Their area is quite small and but little wear would be required to obliterate them.

The oral plates rise sharply above the radials and form a gently convex crown each of whose five loles overhangs the calyx below. Shallow concave depressions occupy the upper surfaces of the orals.

The surface of the holotype is smoothly polished but completely covered by minute irregularities which can be seen only when the specinen is magnified some twenty-five or more diameters. This probably does not represent original ornamentation of the surface but is due to a very slight amount of solution.

Rcmarks.-This species, which is based upon a single individual, is quite similar in a general way to some forms of the $K$. astrus series, but in its combination of characters it differs from any of the $K$. astrus forms examined. This is particularly true in regard to the higher basal disc and less prominent knoblike processes of the radials in an individual whose wiclth is greater than its height, and also in the comparatively larger and more overhanging oral plates. It might be questioned whether these distinctions are sufficiently important to justify specific discrimination from the $K$. astrus series, but they probally are, inasmuch as $K$. litius occurs at a considerably higher horizon.

Occurrence. - The single specimen of $K$. lilius was collected by Mr. J. B. Knight from calcareous shale immerliately below the Piasa limestone in the hollow just north of the right angle west turn of Scheute Road, half a mile southwest of Lackland Station on the Chicago, Rock Island and Pacific Railway and three quarters of a mile north of Stratman. St. Louis County, Missouri.

Kallimorphocrines indinensis J. M. Meller, n. sp.

Plate I, figs. 9a-b

Description.-The holotype is $1.41 \mathrm{~mm}$. in height, of which the radials form about three-fourths. The greatest width is somewhat less than the total height, being approxinately equal to the combined height of the basal disc and raclials. A cross-section through the upper part of the radials is nearly pentagonal, with only slightly concave sides.

The basal disc is low and broad. Its height is about one-tenth of the total height and its width somewhat less than half the greatest width of the cup. It slopes gently outward above the circular stem facet which occupies its whole proximal surface. 
The radials are elongated and are wider above than below. Their height is somewhat more than twice their mean width. A sharp angulation occupies a central position, rising from the general curvature of the basal disc at the base of the radial, becoming stronger and more prominent upward, and ending above in the articular facet. Upon either side of the articular facet the radials are beveled, producing gently concave surfaces into which the orals extend.

The articular facets are strong and well developed although they occupy only about one-third the upper width of the radials. The angulations of the radials are beveled above, producing triangular facets which rise to the trans. verse articular ridges. Behind each transverse ridge and at the bottom of a concave area bounded by radial ridges is the opening of the axial canal.

The orals are prominent though not overhanging and form a five-lobed crown rising above the radials. Their upper flattened surfaces are shallowly concave. The ambulacral openings penetrate between the orals at a position about midway above the articular surfaces of the radials.

The surface of this specimen which is entirely silicified is very uneven. Although this may be the result of alteration, it is probably due, at least in part, to the original structure and porous texture of the plates.

Remarks.-This species which is based upon a single specimen is so distinctive that it is unnecesary to compare it with the other forms described.

Occurrence.-The specinen is from dark limestone near the base of the Pennsylvanian strata in the center of the N. I/2 sec. 35, T. 21 N., R. 9 W., Warren County, Indiana.

\section{Kaleimorpitocrines vanpelti J. M. Weller, 11. sp.}

Plate I, figs. 6a-b

Description.-The height of the holotype. cxclusive of the stem joint attached to the calyx, is $1.30 \mathrm{~mm}$. and is equalled by the greatest width. The radials make up three-fourths, the basal disc about one-ninth, and the oral crown abont one-sixth of the total height of the calyx.

The entire lower surface of the basal disc is occupied by the stem facet above which the disc enlarges rery slightly to its scalloped upper border upon which the radials rest. The diameter of the basal disc is equal to about half the greatest width of the calyx.

The radials are subrectangular in outline and only slightly wider above than below. They are about twice as high as wide. Median angulations developed longitudinally on the radials become progressively more prominent above and are terminated by subtriangular beveled surfaces which rise to the transverse ridges of the articular facets. The upper corners of the radials meet in shallow concave depressions occupied by the outer edges of the orals. 
The articular facets are well developed and strong, consisting of the prominent transverse ridge behind which lies the concave depression containing the opening of the central canal.

The orals rise strongly above lut do not overhang the rachials. Their upper surfaces are shallowly concave and the posterior one bears a small pustule marking the position of the madrepore.

The surface of the caly'x and particularly that of the radials is very rough and uneven and hears numerous small, irregular, closely set spinelike processes. The depressions between them are filled with a brownish argillaceous matrix so that it is impossible to determine whether or not the plates are porous. The surface however strongly suggests that they were composed of a comparatively coarse spicular intergrowth which was not completely transiormed into solid plates.

Remarks.-It is mnnecessary to compare this species with any other as its rough and irregular surface is entirely distinctive.

Occurrence. - The holotye was obtained from shale occirring just below the Piasa limestone near the center of the NE. $1 / 4 \mathrm{sec} .25$, T. $8 \mathrm{~N}$., R. $10 \mathrm{IV}$, Jersey County, Illinois.

\section{Kallimorpiocrints infacftes J. M. Weller, 11. sp.}

Plate II, figs. 4a-b

Doscription.-The height of the holotype is $1.37 \mathrm{~mm}$. which is only slightiy greater than the greatest width. and the diameter of the basal stem facet is about one-half the greatest width. The radials make up about serentenths, the basal disc one-tenth, and the oral crown one-fifth of the total height. The outline as viewed from above is roughly pentagonal but the symmetry is interrupted by the irregular development of the arm facets.

The hasal disc is low and loroad and slopes slightly upward and outward from its large stem facet. Its upper edge is beveled for the reception of the radials.

The height of the raclials is a little less than twice their mean width and they are considerably wider above than below. The angular median keel begins at the lower extremity of the radial and becones more pronounced upward until it ends in the articular facet. The sloping sides of adjoining radials meet at the suture and form the slightly concare or nearly flat sides of the calyx. The upper corners of the radials are slightly heveled. producing shallow concave notches between the arm facets.

The articular processes of the radials are rather unequally developed. They are in general large and well formed and show the same features noted in $K$. pocillus. On the holotype, however, no articular process is present on the anterior radial which perhaps was not arm-learing, but it is also possible that the structure has been obliterated ly wear. In any case this ray is the 
least developed, a condition that has also been noticed in specimens of certain other species.

The oral crown is rather flat and rises abruptly from the radials. In diameter it is only slightly larger than the basal disc and it does not wholly cover the ventral surface of the cup. The individual plates are shallowly excavated and the posterior one bears a pustule indicating the position of the maclrepore.

The surface of the holotype, which is a silicified specimen, is minutely pitted. This probably represents the original porous structure of the plates.

Remarks.-This species resembles $K$. pocillus in size, in the small oral crowil, and in the large and strong articular processes. However, its general form, produced by the angulated radials, serves to distinguish it from the other which is composed of convexly rounded radials.

Occurrence.-The holotype is from a limestone near the base of the Pennsylvanian section near the center of the N. T/2 sec. 35, T. 21 N., R. 9 IT., Warren County, Indiana.

\section{KALLIMORPHOCRINUS SP.}

Description.-The calyx of this poorly preserved specimen is a little less than $1.5 \mathrm{~mm}$. in height and the greatest width is somewhat less. The radials form about two-thirds, and the basal disc and oral dome each make up about one-sixth of the total height of the calyx.

The hasal disc has a diameter equal to about two-thirds of the greatest width of the calyx and is only slightly larger above than below.

The radials are subrectangular and only slightly wider above than below. Their height is about twice their width. Each radial is merlianly angulated and the surfaces slope off on either side to meet the adjoining radials and form the flat lateral sides of the calyx, giving the whole body a truncated pyramidal form.

The articular facets of the radials are largely obliterated and none of the details can be made out.

The oral crown is subhemispherical in form and does not overhang the radials. Its diameter is about equal to that of the basal disc.

The surface of the calyx is badly worn or weathered. Its uneven roughness suggests that the plates are spicular and porous.

Remarks.-This specimen most closely resembles $K$. indianensis but its basal disc is much stouter and it lacks deep notches at the upper corners of the radials. It occurs at a much higher horizon and is probably a distinct species but it is impossible to adequately characterize it from the single inperfect specimen obtained.

Occurrence.-This specimen was collected from a thin layer of argillaceous limestone beneath the thick quarry bed near the south end of the large 
quarry about two miles south of Fairmont, Vermilion County, Illinois. The exact position of this limestone with regard to the standard Illionis section is not definitely known but the horizon is not far from that of the Lonsdale limestone ${ }^{6}$ although it may be somewhat higher.

\section{Kallimorpiocrine's pocilites J. Mi. Weller, n. sp.}

Plate II, figs. la-d

Dcscription.-The calyx is small, the greatest diameter being somewhat less than the height which is $1.48 \mathrm{~mm}$. in the holotype. The horizontal outline is distinctly five-lobed owing to the convex form of the radials whose lateral slopes form broad, more or less deep concavities along the centers of which lie the sutures. The radials form about seven-ninths, and the underlying base anc' the crowning orals each form about one-ninth of the total height. Beneath the base in some of the specimens occurs a thin stem-joint firmly attached to the calyx.

The basals are firmly anchylosed into a low basal disc which slopes gently outward to the slightly excavated suture separating it from the radials. It is nearly circular in outline but is beveled above by five inclined planes upon which the radials rest, thus giving it a somewhat pentagonal appearance. The stem facet occupies the whole lower surface of the basal disc. It is nearly circular, large, with a diameter only slightly less than half that of the calyx, and was probably pierced by a single central opening.

The radials are subrectangular in outline, nearly twice as high as wide, and approximately equal in size. Their outer surfaces are convex buth horizontally and vertically. The vertical convexity occurs chiefly in the lower half and thus the greatest diameter of the calyx occurs at about mid-height. The horizontal convexity increases rapidly from the lower edge of the radials upward to about the middle, beyond which it remains fairly constant. The upper corners of the radials are somewhat notched forming shallow concave grooves sloping upward and inward to the orals.

Each radial bears upon its distal surface an articular facet for the reception of an arm. These do not extend over quite all the willth of the radials but are separated from each other by the shallow concave grooves mentioned above. There is more variation in the size of the articular processes than in any other part of this crinoid. Commonly that of the anterior radial is the smallest and those of the posterior radials largest but the gradations in size are not at all regular.

The orals form a rather flat-topped crown rising sharply above the radials. In diameter and height the crown is nearly equal to the basal disc and is on the whole less conspicuous in this than in most of the other species here described. The oral plates are nearly uniform in size, the posterior one

\footnotetext{
In the Pcoria district, the Lonsdale limestone occurs about 120 feet above coal No. 6.
} 
however being slightly wider than the others. This oral is also distinguished by a tiny pore near its center. Above the radials and along the sutures between the orals in one specimen are five small openings which were probably continuous with the ambulacral grooves of the arms.

The surface of the plates was apparently originally smooth although the specimens, which are silicified, are slightly roughened. The preservation of the plates suggests a minutely porous surface.

Remarks. - This species is typical of the simpler type of Kallimorphocrimus which has a lobed horizontal outline and whose radials have not developed longitudinal angulations. It is unnecessary to compare it with any of the foregoing species.

Occurrence.-This species occurs in a dark limestone not far above the base of the Pennsylvanian section near the center of the $\mathrm{N}$. $1 / 2 \mathrm{sec} .35$, T. 21 N., R. $9 \mathrm{~W}^{\top}$., Warren County, Indiana.

\section{Kallimorphocrinus illinorsensis J. M. Wellet, n. sp.}

Plate II, figs. 2a-3b

Description.-The calyx is small and the width considerably exceeds the height which in the holotype is $1.30 \mathrm{mmm}$. The outline of the cup as seen from above or below is strongly five-lobed owing to the very convex radials, whose margins meet at an angle along the suture. The radials form about four-fifths, and the basal disc about one-twelfth of the height, and the oral crown is twice as high as the basal disc.

The basal disc is low and pentagonal in outline as viewed from beneath. Its upper edge is cut by five deep scallops for the reception of the radials. The circular stem facet does not occupy the entire under surface of the disc; its surface is shallowly concave surrounded by a raised border.

The radials are suboval in outline, about one and a half times as high as wide. Their outer surfaces are strongly convex both longitudinally and laterally. The longitudinal convexity is most pronounced in the lower half of the radials, resulting in the greatest width of the calyx being developed at a position about one-third of the distance above the base. The upper outer edges of the radials are beveled and their distal surfaces are occupied by articular processes for the attachment of the arms. The upper corners of the radials are beveled so that the arm facets are separated by small and shallow concave notches in which the orals rest.

The articular processes are not well preserved but they appear to be similar to those of the other species here described.

The calyx is surmounted by a five-lobed oral crown which does not overhang the radials. The upper surface of each oral is loroadly and shallowly concave. 
The surface of the holotype is smooth and entirely unornamented.

Remarks.-In some respeets this species resembles $K$. pocillus but the proportions are different and its radials are much more convex, thus giving a more pronounced lobation to its horizontal outline.

Occurrence. - The holotype was obtained from shale directly underlying the Piasa limestone near the center of the NE. I/4 sec. 25, T. $8 \mathrm{~N}$., R. $10 \mathrm{~W}$., Jersey County, Illinois. The other figured specimen was collected by Mr. J. B. Knight from the same stratigraphic horizon in the hollow just north of the right-angle west turn of Scheute Road half a mile southwest of Lackland Station on the Chicago. Rock Island and Pacific Railway and three quarters of a mile north of Stratman, St. Louis County, Missouri.

\section{Kallimorphocrines knighti J. M. V'eller, 11. sp.}

\section{Plate I, figs. $7 \mathrm{a}-\mathrm{b}$}

Description. - The height of the holotype is $1.48 \mathrm{~mm}$. and the greatest width is approximately the same. Its outline as scen from above is subpentagonal. The corners which are formed by the rounderl angulations of the radials are more or less narrowly rounded and the sides of the radials meet at a very obtuse angle. The radials make up about threc-fourths, the basal disc one-twelfth, and the oral crown one-sixth of the total height. A thin circular stem joint is attached to the base of the calyx.

The basal disc is subpentagonal with slightly convex sides. It slopes strongly outward and upward from the proximal stem facet which occupies most of its basal surface. The upper edge of the disc is cut by five sharp scallops in which rest the raclials.

The radials are oval below and truncated above. Their height is consiclerably less than twice their greatest wiclth. The median portions of the radials are produced into narrowly rounded longitudinal angulations from which nearly flat sides slope off to the sutures along which the adjacent radials meet at a very oltuse angle. The lateral profile of the radials is convex with the curvature largely localized near the middle so that the greatest width of the calyx occurs at about mich-height. The upper outer edges of the radials are partially beveled and the upper corners are depressed, producing shallow concave notches in which the orals partially extend.

The articular processes of the radials on the holotype have been partially olliterated but they were apparently large and strong. One of the radials, the anterior one probably, is somewhat larger than any of the others but not large enough to greatly mar the pentamerous symmetry.

The oral crown, although prominent, does not extend completely to the edge of the radials at their junctions. This portion of the crinoid is rather worn but the details of its structure, such as the shallow depressions of the 
upper surfaces of the orals, are quite similar to those in the other species here described.

The surface of the basal disc and radials is beautifully ornamented by thickly grouped, small, low or irregularly rounded pustules.

Remarks.-This most striking species of Kallimorphocrinus can not be confused with any other form as its shape and ornamentations are entirely distinctive.

Occurrence.-The holotype of this species was collected by Mr. J. B. Knight from the limestone overlying the horizon of the Belleville (No.6) coal about 200 feet west of Louisville Avenue on West Park Avenue, Cheltenham district, St. Louis, Missouri.

\section{Kallimorphocrinus eypanses J. M. Weller, n. sp.}

Plate I, figs. $10 \mathrm{a}-\mathrm{b}$

Description.-The greatest width of the calyx considerably exceeds the height which in the holotype is $1.04 \mathrm{~mm}$. The radials constitute about tenthirteenths of the height and the basal disc and oral crown make up respectively about one-thirteenth and two-thirteenths of the total height. The horizontal outline of the calyx is stellate with bluntly rounded angles and concave sides.

The basal disc is pentagonal as viewed from below and its diameter is equal to less than half the greatest width of the calyx. Its lower surface is entirely occupied by a circular, slightly concave stem facet above which it slopes upward and outward to the radials which rest in scallops cut in the upper outer edge of the disc.

The height of the radials is equal to somewhat less than twice their mean width and they are a little more than one and a half times as wide above as below. These plates are convex both longitudinally and transversely. The transverse convexity is largely localized to form a median longitudinal, more or less narrowly rounded angulation from which the plates slope off gently to form the concave sides of the calyx. The longitudinal convexity is fairly regular and the greatest width of the calyx occurs near the upper edges of the radials. The upper outer corners of the radials are rounded off and produce at their junction concave depressions into which the orals extend.

The articular facets on the upper surfaces of the radials are not well preserved but as far as may be olserved they are comparable to those of the other species of this genus.

The oral crown rises abruptly above the radials but does not overhang them. The details of this part of the calyx are somewhat olscure but the oral plates are apparently similar in form and arrangement to those seen in the better preserved specimens of other species. 
The surfaces of the plates are smooth and the caly'x is entirely unormamented.

Rcmarks. - This species most closely resembles $K$. illinoiscnsis with which it is associated but is easily distinguished by the smaller size, the narrower rounding of its radials, and the fact that the greatest width is attained near the upper border of the radials.

Occurrece.-The holotype and several other specimens were obtained from shale immediately nnderlying the Piasa limestone near the center of the NE. I/4 sec. 25, T. 8 N., R. 10 W., Jersey County, Illinois.

Genus AIDEMOCRINUS J. M. Weller, n. gen.

Genotype Aidenocrinus odiosus J. M. Weller, n. sp.

This genus is introduced to accommodate a single species of tiny armless crinoid whose calyx is composed of three rings of plates without a lateral anal opening. It is tentatively assigned to the family Allagecrinidae.

Aidemocrinus odiosus J. M. Meller, n. sp.

Plate II, figs. 5a-b

Description.-The calyx is very small. The height of the holotype, which is $.55 \mathrm{~mm}$, is equal to about one and one-third times the greatest

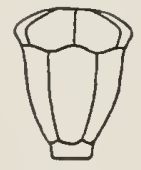

FIG. 3 Interpretation of the calyx structure of Aidcmocrinus odiosus (compare with P1. II, fig. 5 a).

width. Although the sutures are not shown as clearly as might be desired there can be little doubt concerning the structure of the calyx. It is composed of three rings of plates which are interpreted as, (1) a basal disc, (2) five equal radials, and (3) an oral dome of five subequal plates. The calyx is subpyramidal and rises from the moderately sized proximal stem facet to the gently convex distal surface.

The basal disc makes up about one-eleventh of the total height of the calyx. Its proximal surface is occupied by a circular stem facet having a diameter equal to about one-third of the greatest width of the calyx, and pierced liy a single sinall central opening. The basal disc rises nearly vertically from the stem facet to its upper edge which is gently scalloped for the reception of the radials.

The radials form about two-thirds the height of the calyx, are about twice as wide above as below, and about twice as long as the greatest width. They are subovel below and above they are apparently more sharply truncated. The upper edges of the radials are not very well defined. but the corners appear to be rounded off. meeting in gently concave depressions in which the orals rest. A rounded longitudinal ridge is developed down the center of each radial. This ridge is beveled above producing a triangular area 
which slopes gently upward to the orals. The lateral surfaces of the adjoining radials meet to form a nearly plane surface in the middle of which is the interradial suture.

No structures for the support of arms are developed on any of the radials nor is an anal opening visible in the calyx.

The oral dome, formed of five nearly equal plates which alternate with the radials, constitutes a little more than a quarter of the total height of the calyx and overhangs the radials so that when viewed from above none of the lower plates are visible. The relation of the orals at the center of the distal surface is not entirely clear but it appears that the two anterior plates extend beyond the left and right posterior orals and fit into a notch in the end of the posterior plate in the manner characteristic of Dichostrebloci inus scrobiculus. They slope gently outward and downward from the center and then turn sharply downward to meet the upper edges of the radials. The tipper surfaces of the orals have shallow depressions similar to those developed on the oral plates of Kallimorphocrinus.

The surfaces of the plates are minutely irregular and porous.

Rcmarks. - The systematic disposition of this little crinoid is a rather perplexing problem. It is strikingly similar in form and appearance to certain examples of Kallimorplocrinus and differs from this genus only in the absence of arms and in the apparent relation of the orals at the center of the distal surface which resembles Dichostreblocrinus rather than Kallimorphocrinus. A. cdiosus can not be considered an immature stage in the development of Kallimorphocrinus however as we have six similar specinens and no intermediate stages.

On the other hand $A$, odiosus is very similar to certain specimens considered to be inmature stages of Dichostreblocrinus scrobiculus (p. 37). From these however it differs in its more slender proportions and in the character of the distal surface of the orals.

Were it not for the character of its oral crown $A$. odiosus night be referred to the Hypocrinidae. In this case the intermediate ring of plates would have to be considered basals and the calyx structure would differ from Acariniocrinus only in the absence of a lateral anal opening.

Occurrcuce.-These silicified specimens were obtained from a limestone low in the Pennsylvanian section of Warren County, Indiana, near the center of the N. T/2 sec. 35, T. $21 \mathrm{~N} ., \mathrm{R} .9 \mathrm{IV}$.

\section{FAMILY HYPOCRINIDAE}

The fanily Hypocrinidae was erected by Wanner in 1916 who assigned to it Hypocrimus Beyrich. Sycocrinus Austin, Cydonocrinus Bather and the new genera Monobrachiocrimus, Thetidocrinus and Bolbocrinus [1t, p. 88]. 
At the same time he introduced the family Embryocrinidae based upon the new genus Embryocrimus [14, p. 130].

In 1920 Wanner discussed in detail the relationships of the various members of the Hypocrinidae [15]. At this time he alandoned the Embryocrinidae and added to the Hypocrindae the following genera, Embryocrinus NVanner, Lagcniocrimus de Koninck and Le Hon, Cocnocystis Girty and the

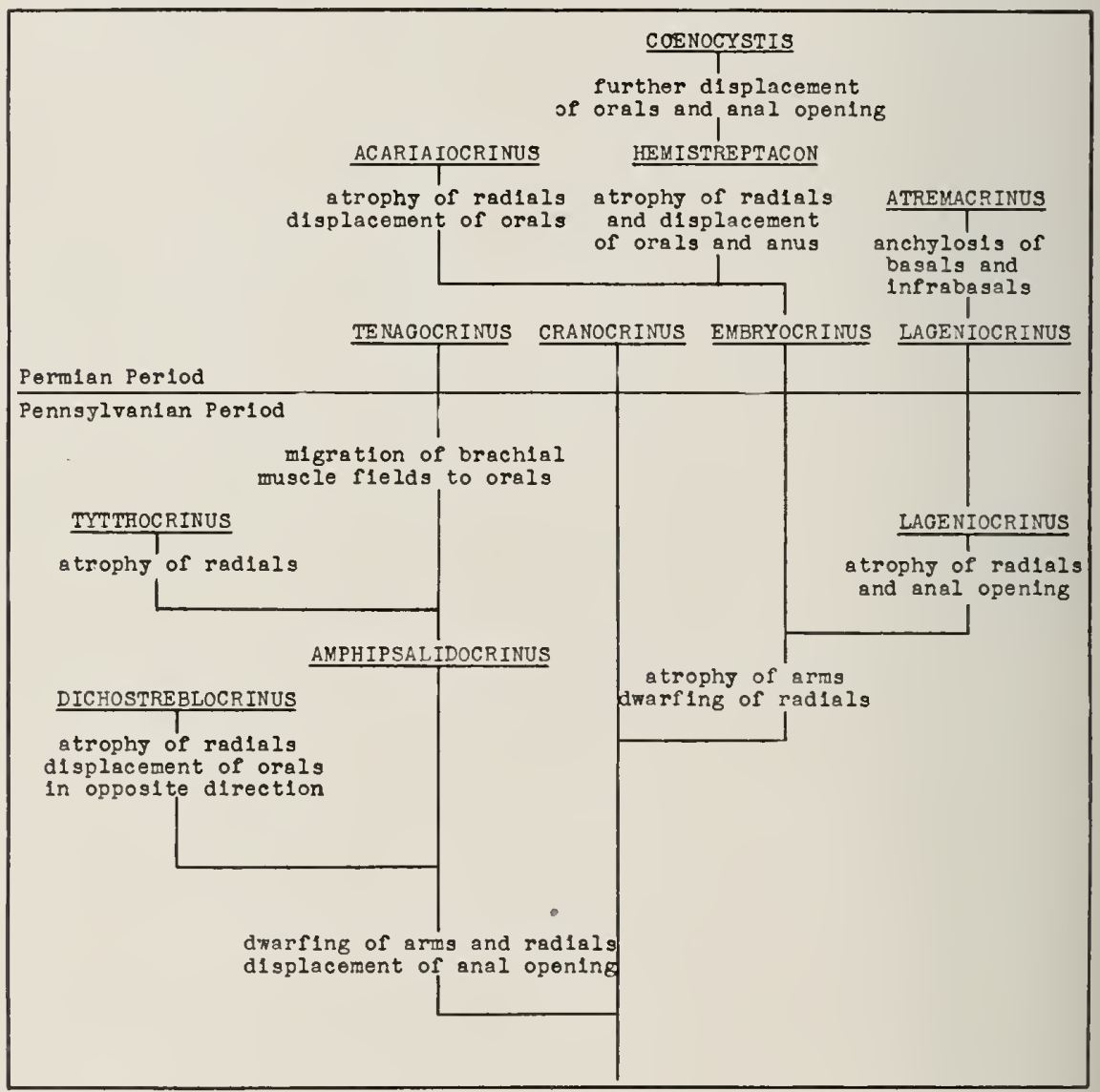

FIG. 4

new genera Mctasycocrimus anci Aürachiocrimus based upon previously described species. In 1923 two more new genera. Allosy'cocrimus and Acariaiocrimus were added to the Hypocriniclae $[16, \mathrm{p}, 133 \mathrm{ff}]$.

In a more recent paper Wanner has further expanded this interesting family by the addition of Hcmistreptacon Jakovlev and the new genera Tenagocrinus, Cranocrimus, and Atremacrimus $[17, \mathrm{p} .84 \mathrm{ff}]$. 
Wanner is of the opinion that this group of crinoids forms a degenerate series which developed from more complex ancestors by the partial or complete atrophy of the radials and arms, displacement of the anal opening from its normal posterior position toward one of the neighboring radii or completely out of the dorsal cup of the crinoid, and displacement of the oral plates from their original interradial position to a more or less perfectly radial position.

Our Pennsylvanian collections contain a group of small crinoids whose characters ally them to the Hypocrinidae. They are assigned to Lageniocrimus de Koninck and Le Hon and the three new genera Amphipsalidocrinus, Tythocrinus, and Dichostrcblocrinus. Their relations and their probable evolution is shown in the diagram (Fig. 4) of a portion of the Hypocrinidae which is modified after $1 \mathrm{Vanner}[17$, p. 98].

\section{Genus LAGENIOCRINUS de Koninck and Le Hon 1854}

Genotype Lageniocrinus seminulus de Koninck and Le Hon

The genus Lagcnioc?inus was established upon a small species of crinoid which is very rare in the Lower Carboniferous limestone of Visé, Belgium $[3$, p. 187]. This crinoid is composed of three rings of plates which were originally interpreted as a circle of three basals and two radial circles of five plates each, forming a completely enclosed flagon-shaped body. It was suggested that this small crinoid is transitional between the Platycrinidae and the Blastoidea. Zittel regarded the upper ring of plates as arm joints [18, p. 350] and this view was shared by Wachsmuth and Springer [13, p. 175] who suggested that this crinoid was possibly a young stage of Synbathocrinus. Later both Bather [1, p. 152] and Springer [9, p. 209] placed Lagcmiorrinus in synonomy under Symbathocrinus.

In a detailed discussion incidental to his description of the new genus Enbryocrimus. Wanner returned Lageniocrinus to an independent generic standing, pointed out its very primitive character, comparing it to a larval stage of the living Antedon and distinguished the upper circle of plates as orals $[14$, p. 134].

More recently, Jakovlev has offered the opinion that the isolated specimens of Lageniocrimus that have hitherto been found are simply abnormal examples of other more common crinoids [6, p. 313]. This view resulted from his study of a series of nearly a thousand specimens of Hemistreptacon abrachiatus from the Permo-Carboniferous of the Ural Mountains among which he found one example similar in structure to Lageniocinins but apparently connected by intermediate stages with Hemistreptacon.

Six specimens of a minute crinoid which is constructed similarly to the genotype of Lageniocrimus, all obtained from the same locality, are of approximately sinilar size and must be regarded as mature individuals for they 
are not associated with any other crinoirl with which they might be connected as alserrant examples. It is necessary therefore to follow Wanner in his opinion that Lagcuiocrinus is a valicl genus.

LAGENIOCRINi S CASSIDL'S J. M. Weller, n. Sp.

Plate II, figs. 6a-b

Description.-The calyx is subghobular and very small, the height of the holotype being $.74 \mathrm{~mm}$. and the largest specimen obtained $92 \mathrm{~mm}$. The

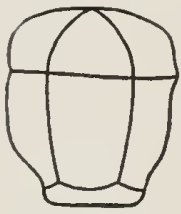

Fig. 5

Interpretation of the calyx structure of Lageniocrinus cassus ( compare with Pl. II, fig. 6a). sutures between the plates are not clearly visible, but the calyx appears to be composed of three rings of plates which are interpretated as, (1) a low more or less compressed infrabasal disc. (2) five equal basals, and (3) five approximately equal orals. Of these the basals make up the greater part of the height of the calyx.

The infrabasal disc is somewhat variable in the lifferent specimens. In the holotype it is low and platelike with a large round proximal stem facet. In some of the others however it is somewhat higher and possesses a smaller stem facet and consequently is obtusely fumnel-like in form. It is pierced by a single small central canal.

The size and shape of the basals are somewhat difficult to describe owing to the questionable position of the sutures bounding them above. Interpreted in accordance with figure 5 they are somewhat less than twice as high as wirle, rouncled below, evenly truncaterl ahove and bounderl laterally by nearly parallel sides. Near the midlle they are swollen into broad rounderl areas which stand out prominently above the infrabasal disc. Above each of these swellings is a diamond shaped area formed of two flat equilaterally subtriangular areas, the lower of which occupies the upper part of the basal while the upper one is formed by the outer proximal portion of the superjacent oral. These areas slope inward slightly and meet each other at an obtuse angle.

The oral crown forms a nearly circular cover extending over the entire ventral surface of the body. It is composed of five equal oral plates which are disposed in series above the basals. The interoral sutures are not clearly shown but they appear to be situated at the bottoms of five radiating troughs which extend outward from the center of the oral crown.

No anal opening is present in the side of the calyx.

Rcmarks.-This species deviates greatly from the simple pyriform shape of the genotype but its structure conforms perfectly to that of Lagcuiocrinus and it is referred to this genus without hesitation.

Occurcucc.-Collected from limestone near the base of the Pennsyvanian near the center of the $\mathrm{N}$. T/2 sec. 35, T. $21 \mathrm{~N}$., R. $9 \mathrm{NT}$., $\mathrm{N}^{\mathrm{T}}$ arren County, Incliana. 
Genus AMPHIPSALIDOCRINUS" J. M. Weller, 11. gen.

Genotype Amphipsalidocrinus scissurus J. M. Weller. n. sp.

Wanner has recently described two new genera of crinoids-Cranocrimus and Tcnagocrinus-from the Permian deposits of Timor which are composed of an infrabasal disc, five basals, five radials and five orals with a lateral anal opening piercing the cup $[17, \mathrm{pp} .41,48]$. Tonagocrinus differs from Cranocrimus in that its radials are shrunken so that they no longer meet laterally and the anal opening has been drawn toward the right from the center of the posterior interradius so that the calyx is no longer synmetrical. In Cranocrinus the oral plates are concave and meet each other along ridges which radiate from the center of the crown. In Tenagocrinus the orals are convex and meet in rounded furrows which apparently served as protective receptacles for the contracted arms. Moreover in this genus the stunted radials no longer bore fields for the attachment of the brachial muscles but in a most peculiar fashion the muscles in these forms were attached to sunken areas near the proximal corners of the orals.

In our collection there is an interesting little crinoid which appears to be intermediate between Cranocrinus and Tcnagocrimus. Although the sutures cannot all be clearly seen, the oral dome resembles that of Cranocrimus whereas the dorsal cup appears to be identical with Tcnagocrinus. For the reception of this crinoid the new genus Amphipsalidocrinus is introduced. This genus differs from the typical examples of Cranocrimus in possessing shrunken radials and an anal opening which has heen drawn to the right from the center of the posterior interradius and it differs from Tcnagocrinus in not being furnished with interoral furrows into which the fields of attachment of the brachial muscles have migrated.

Amphipsalidocrinus scissurus J. M. Weller, n. sp.

Plate II, figs. 8a-c
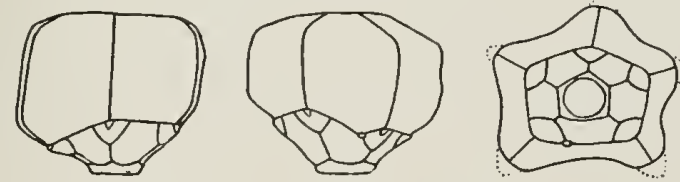

FIG. 6

Interpretation of the calyx structures of $1 m p h i p s a l i-$ docrinus scissurus (compare with Pl. II, figs. $8 \mathrm{a}, \mathrm{b})$.

Description.-The calyx of the holotype is $.63 \mathrm{~mm}$. in height and of slightly greater maximum breadth. It is mushroom shaped, expanding rapidly from a moderately sized stem facet into a large, over-hanging star-shaped

${ }^{8} \dot{a} \mu \phi i$, (stretching) around; $\psi$ a $\lambda i s$, dome. 
vault. Nlthough the sutures between the plates can not be made out with certainty the plates are probably arranged as follows: (1) a low and small infrabasal disc: (2) a ring of five rather short irregular and somewhat unequally sized basal plates; (3) five stunted radial plates that do not meet laterally; and (4) a comparatively large inflated vault composed of five oral plates.

Although the details of the basal disc can not be determined it is undoubtedly low and saucer shaped and its lower part slopes steeply downward to the circular stem facet.

The basal plates are probably rather irregularly sub-hexagonal in outline and of somewhat different size. The proportion of height to width varies but the dimensions are approximately the same. The height of these plates differs however with the result that the little radial plates stand at varying distances above the base of the calyx.

The radials are very small. Near the middle of the upper edge of each occurs a small triangular drooping lip which is interpreted as an arm facet. The arms must have been very small. No articular processes have been olserved in connection with these nor are openings into the interior of the calyx visible.

The anal opening is situated slightly below the level of the right posterior arm facet and much nearer this than the left posterior facet. It is very small but rendered conspicuous by a curved outstanding lip which occurs beneath it.

The oral vault makes up by far the greater part of the calyx. The individual plates are of approximately equal size and shape except that the posterior oral is somewhat wider than the others. As they slope gently outward from the center of the ventral surface the oral plates become broadly concave between their somewhat upraised edges which meet and form five broadly rounded radiating ridges. As the orals curve sharply downward to form the upper part of the sides of the calyx their median concave depressions persist but their edges prolnably produced sharp angular vertical ribs strongly developed to a positon only a short distance above the arm facets. These vertical ribs have been lorolien off from the holotype however and appear in this specimen as narrow slits leading into the interior of the calyx.

The surface of the holotype, which is silicified, is rather rough probably indicating that the plates were originally minutely porous.

Rcmarks.-This species closely resembles certain abnormal specimens of Cranocrinus figured by Wanner [17, pl. 1. figs. 10, 11]. but its association with Tythocrinus comptus, described below, is evidence that it is actually the normal representative of a type intormediate between Cranocrimus and Tenagocrinus. 
Occurrence.-The holotype, which is entirely silicified, was obtained from a dark limestone near the base of the Pennsylvanian strata near the center of the N. I/2 sec. 35, T. 21 N., R. 9 W., Warren County, Indiana.

Genus TITTHOCRINUS J. M. Weller, 11. gen.

Genotype Trttiocrinus comptus J. M. IVeller, n. sp.

Tytthocrinus differs from Amphipsalidocrimus in the further degeneration of its radials and arms. This form is armless and the radials are either exceedingly minute or absent. The anal opening has been displaced farther to the right and lies nearly in the right posterior radius.

\section{Tyttiocrints comptus J. M. Weller, n. sp.}

Plate II, figs. 7a-b

Description.-The calyx is very small and somewhat broader than high. The height of the holotype is :44 mm. The body expands rapidly from a

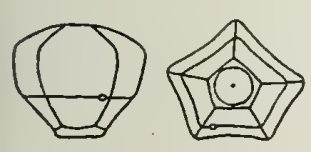

Fig. 7

Interpretation of the calyx structure of Tytthocrinus comptus (compare with $\mathrm{Pl}$. II, fig. $7 \mathrm{a}$ ). moderately sized stem facet to the gently sloping subpentagonal distal surface. The arrangement and number of the plates is not certainly known because of the indistinct sutures separating them, but they appear to be disposed in three circles, (1) a very low infrabasal disc, (2) a ring of low basals, and (3) five large orals which inclose the greater part of the body cavity.

The infrabasal disc is very low and forms about one-eleventh of the total height of the calyx. Its lower surface is the circular stem facet having a diameter equal to about two-fifths of the maximum width of the body. It is flat and pierced by a single central opening. The sides of the infrabasal disc rise nearly vertically and the position of its upper margin is marked by a very slight constricticn which passes around the crinoid just above its base beyond which small obtuse points project into the angles between the basals.

The basals are low and form about three-elevenths of the total height of the calyx. The sutures separating them can not be made out but the basals are apparently subpentagonal in outline and somewhat wider than high. It is possible that some of them are larger than others. No indication of radials has been observed.

The comparatively large anal opening is situated between the ring of basals and the orals. Although it occurs in the posterior interradius it is strongly displaced to the right, nearly to the right posterior radius.

จrviós, small. 
The oral plates with the exception of the posterior one are of approximately similar size and shape. The posterior oral however is somewhat wider than the others and its upper extremity fits in between the anterior orals thus scparating the left and right posterior plates. The oral dome constitutes about nine-elevenths of the total height of the calyx. The plates slope gently outwarl and downward from the center of the distal surface to a position alout three-elevenths of the total height below the top of the calyx, at which position the greatest width is attained. They are then deflected sharply downward and slope inward to meet the basals below. The oral plates are gently concave transversely and they meet along rounded ridges which stand out most prominently at the angle between the upper and lateral surfaces.

The surfaces of the plates are roughened by very fine irregularities.

Remarks.-This species is the most abundant of the tiny silicified crinoids collected in Warren County, Indiana. About forty specimens have been examined and nearly all of them are comparable in size to the holotype. Were specimens of this species rarer and those of Amphipsalidocrimus scissurus more abundant it would he naturai to conclude that the present form is simply an immature representative of the latter species. The only conspicuous difference between these two is the presence or alosence of the arms. The larger species was arm-bearing and it is easy to conceive that the arms were not developed until the indivicluals had grown to a size exceeding that of the smaller form. However, the numerical disparagement is such that this can not be the case and there is no cloubt but that the smaller forms are mature individuals of a rifferent species.

Occurrencc.-This species was obtained from a linestone in the lower part of the Pennsylvanian deposits of Warren County, Indiana, near the center of the N. T/2 sec. 35, T. $21 \mathrm{~N}$., R. $9 \mathrm{IV}$.

\section{Genus DICHOSTREBLOCRIN L'S J. M. Weller, n. gen.}

Genotype Dichostreblocrints scrobicllés J. M. Meller, n. sp.

The subpyriform calyx is composed of three rings of plates which are interpreted as, (1) an infrahasal disc, (2) five basals, and (3) five orals. The laterally situated anal opening has been clisplaced to the right from the posterior interradius nearly to the right posterior radius and lies in a deep scallop in the upper right-hand corner of the posterior basal. The orals on the other hand have been slightly displaced to the left so that they are no longer exactly interradial in position.

A number of armless crinoids of somewhat similar calyx structure are lnown in which displacement of the orals or of the anal opening has taken

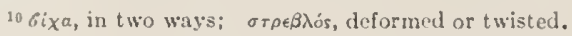


place. The following table summarizes the distinguishing characters of the various genera:

Hemistreptacon Jakovlev

Cocnocystis Girty

Acariaiocrinus Wanner

Dichostrcblocrinus J. M. Weller, 11. gen.

Tytthocrinus Weller, n. gen.

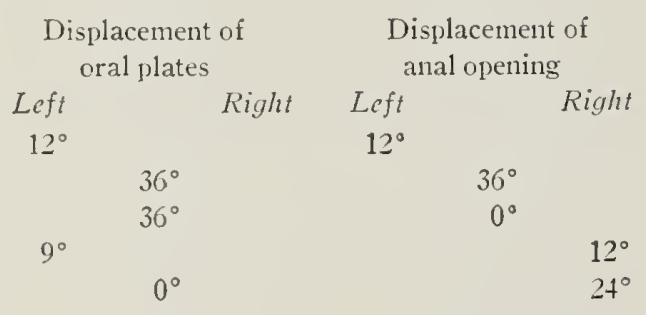

Dicimostreblocrint's scrobicult's J. M. Weller, n. sp.

Plate II, figs. 9a-d

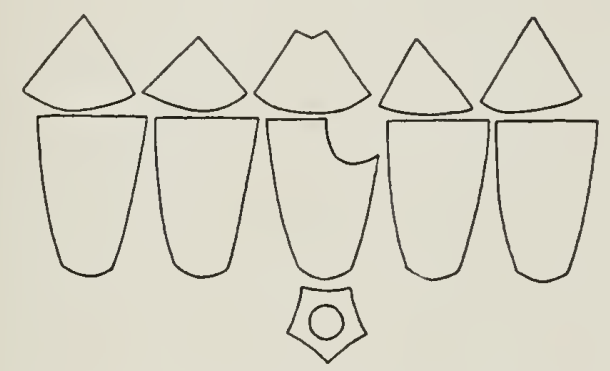

FIG. 8

Plan of the calyx of Dichostrcblocrinus
scrobiculus

Description.-The holotype has a height of $1.78 \mathrm{~mm}$. which is about one and a half times its greatest breadth. The calyx is subpyriform with a subcircular, subpentagonal cross-section. It is composed of three rings of plates. (1) a small infrabasal disc, (2) five approximately equal basals, and (3) five subequal orals.

The form and size of the infrabasa! disc is not known as the sutures separating it from the basals are not distinguishable, but it probably makes up about one-sixth of the total height of the calyx. From the moderately sized stem facet pierced by a single central opening it slopes upward and outward to the basals.

The basal plates constitute about two-thirds of the height of the calyx. They are wider above than below, sharply truncated above and probably suboval below, and their height is equal to about one and one half times the greatest width. Each basal plate bears a longitudinal more or less broadly rounded ridge from which the plate slopes away on either side to join its neighbors in the flat or gently concave lateral sides of the calyx. The basal plates are rather regularly and miformly shaped but the longitudinal ridges are commonly somewhat inclined to the axes of these plates and thus produce 
an anomalous appearance as though the lower part of the calyx had been twisted.

The large anal opening is situated in a deep scallop in the upper righthand corner of the posterior basal. It lies largely within this plate but is also bordered by the right posterior basal, and the posterior and right posterior orals.

The oral dome covers the entire ventral surface of the caly'x and constitutes about one-fourth its height. The oral plates are triangular above except for the posterior one whose upper angle is notched to receive the ends of the anterior orals. The upper surfaces are flat but the edges are rather sharply upraised and the orals meet along five radiating ridges. At the edge of the ventral surface the oral plates bend sharply downarel to meet the basals below.

The entire surface of the holotype is covered with comparatively large but unequally sized and irregularly arranged pits. They are largest and most conspicuous on the oral plates and clecrease notably in size or are alssent iear the sutures which in this way only are distinguishable.

Remarks.-I have inclucled in a single series a considerable number of specimens ranging in size from about $.5 \mathrm{~mm}$. to the holotype which is the largest, considering the smaller ones to be immature examples. The second specimen figured on Plate II $(9 \mathrm{~d})$ is the second largest. This and the holotype alone show the lateral anal opening, and were there not two specimens this opening would have heen consiclered an accidental break, so peculiar is its situation. The smaller specimens also cliffer from the larger in not being so conspicuously pitted, nor is the twisting of the calyx apparent in then. This series seems to show that the displacement of the orals and the appearance and clisplacement of the anal opening are features which were progressively developed during the growth of this crinoid, sulstantiating a similar opinion formed by Jakovlev [6] from a study of a large number of specimens of Hemistreptacon.

Occurence.-These silicified specimens were obtained from a limestone near the base of the Pennsylvanian section in the center of the $\mathbb{N} .1 / 2$ sec. 35 , T. 21 N., R. 9 W., Warren County, Indiana. 
PLATES AND EXPLANATIONS 


\section{EXPLANATION OF PLATE I}

All figures are enlarged fifteen diameters except $3 c$ which is enlarged twenty diameters.

Figs. 1a-c. Hybochillocrinus americanus (Rowley)....................... p. 13

1a. A specimen in which the anal plate has been preserved, scen from the right posterior radius.

1b. Another specimen showing the beveling of the upper left-hand corner of the radial in which the anal plate rested (seen from the same position as 1a).

1c. Ventral view of the specimen shown in $1 \mathrm{~b}$.

Figs. 2a-c. Kallimorphocrinus astrus typicus J. M. ITeller, n. sp., n. var....p. 17

2a. Lateral view of the holotype.

2b. Dorsal view of the holotype.

2c. Ventral view of a specimen having a broken oral crown.

Figs. 3a-c. Kallimorphocrinus astrus intermedius J. M. Weller, n. var......p. 18

3a. Lateral view of the holotype.

3b. Dorsal view of the holotype.

$3 c$. Oral crown of the same showing an abnormal relation of the plates (x 20).

Figs. 4a-c. Kallinorphocrinus astrus pyarimidals J. M. W'eller, 11. var......p. 18

4a. Lateral view of the holotype.

4b. Dorsal view of the holotype.

4c. Ventral view of the holotype.

Figs. 5a-b. Kallimorphocrinus piasaensis J. M. Weller, 11. sp.............p. 18

5a. Lateral view of the holotype.

5b. Ventral view of the holotype.

Figs. 6a-b. Kallimorphocrinus vaspelti J. M. Weller, n. sp.............. p. 21

6a. Lateral view of the holotype from the left posterior radius.

6b. Ventral view of the holotype.

Figs. 7a-b. Kallinorphocrixus KNigiti J. M. Weller, 11. sp................ 26

7a. Lateral view of the holotype from the right anterior radius.

7b. Dorsal view of the holotype, the anterior radius is above.

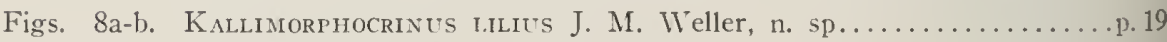

8a. Lateral view of the holotype.

8b. Ventral view of the holotype.

Figs. 9a-b. Kallimorphocrinus indianensis J. M. Weller, n. sp............ p. 20

9a. Lateral view of the holotype.

9b. Ventral view of the holotype.

Figs. 10a-b. Kallimorphockinus expansus J. M. Weller, n. sp.............. 27

10a. Lateral view of the holotype.

10b. Dorsal view of the holotype. 


\section{EXPLANATION OF PIATE II}

All figures are enlarged fifteen diameters except $1 \mathrm{~d}$ which is enlarged twenty diameters.

Figs. 1a-d. Kallimorpilocrinus pochllus J. M. Weller, 11. sp.............. 24

1a. Lateral view of the holotype.

1b. Dorsal view of the holotype.

1c. Ventral view of the holotype.

1d. Detail of a radial arm facet (x 20).

Figs. 2a-3b. Kalindorphocrines illinoisensis J. M. Weller, n. sp............ 25

2a. Lateral view of the holotype.

2b. Dorsal view of the holotype, uppermost stem joint attached.

3a. Lateral view of a spccimen from St. Louis without the uppermost stem joint.

3b. Dorsal view of the same speeimen.

Figs. 4a-b. Kallimorpinocrine's infacett's J. M. Weller, n. sp............... p. 2?

4a. Lateral view of the holotype from the right posterior radius.

4b. Ventral view of the holotype.

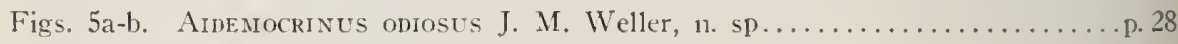

5a. Lateral view of the holotype.

5b. Ventral view of the holotype.

Figs. 6a-b. Lageniockinus cassides J. M. Weller, 11. sp................. p. 32

6a. Lateral view of the holotype.

6b. Ventral view of the holotype.

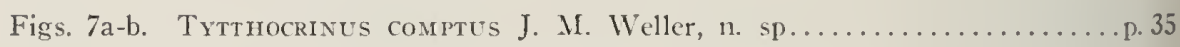

7a. Lateral view of the holotype, from the posterior interradius.

7b. Ventral view of the holotype.

Figs. 8a-c. Amphirsalibochines scissurus J. M. Weller, n. sp............... 33

8a. Lateral view of the holotype, from the postcrior interradius.

8b. Lateral view of the holotype, from the anterior radius.

8e. Ventral view of the holotype.

Figs. 9a-d. Dichostreblocrinus scrobiculus J. M. Weller, n. sp.............. 37

9a. Lateral view of the holotype, from the left posterior radius.

9b. Lateral view of the holotype, from the left anterior radius.

9c. Ventral view of the holotype.

9d. Lateral view of another specimen, from the posterior interradius. 


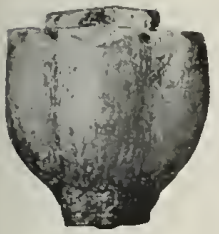

la

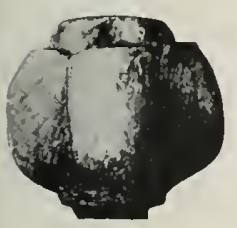

$2 a$

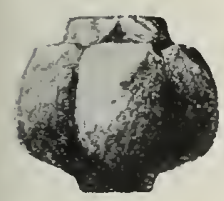

$3 a$

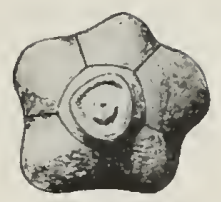

lb

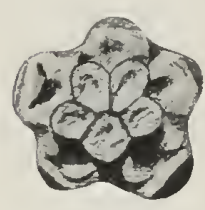

1c

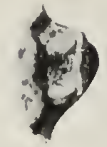

Id

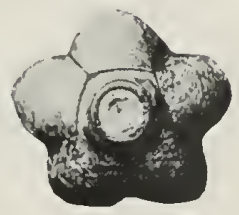

2b

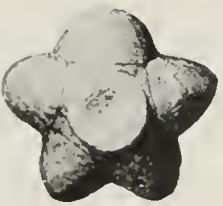

3b

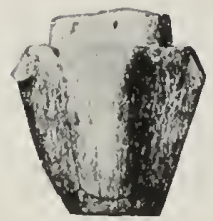

$4 \mathbf{a}$

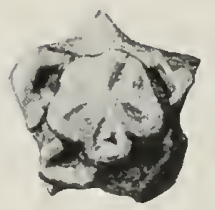

4b

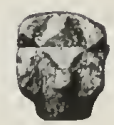

$6 a$

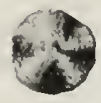

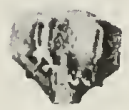

$6 b$

$8 a$
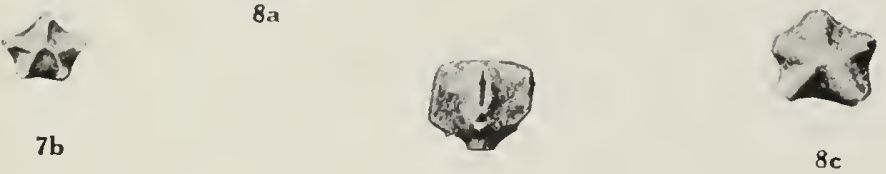

$8 b$

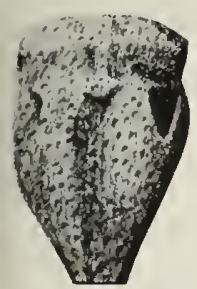

$9 a$

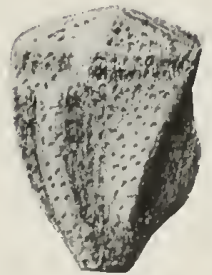

9b
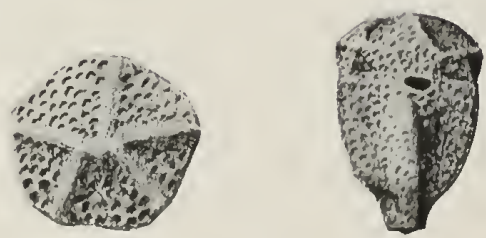

$9 c$ 9d 

CHER'S"

IBRARY BMIDERS

502 S. Goodwtin

Urbana, IIL 
